This is the final revised text and figures accepted by Géotechnique for publication on 16 December 2014.

\title{
Mechanical and hydrological impacts of tree removal on a clay fill railway embankment
}

Smethurst J A, Briggs K M, Powrie W, Ridley A, Butcher D. J. E.

Dr Joel A Smethurst (Corresponding Author)

BEng PhD

Lecturer in Geotechnical Engineering

Faculty of Engineering and Environment

University of Southampton

Lanchester Building

University Road

Southampton SO17 1BJ

Tel: 02380598454

E-mail: jas@ soton.ac.uk

Dr Kevin M Briggs

MEng EngD

Lecturer in Geotechnical Engineering

Department of Architecture and Civil Engineering

University of Bath

Claverton Down

Bath BA2 7AY

Tel: 01225386269

E-mail: k.m.briggs@bath.ac.uk

Prof. William Powrie

FREng MA MSc PhD CEng FICE

Professor of Geotechnical Engineering

Faculty of Engineering and Environment

University of Southampton

Lanchester Building

University Road

Southampton SO17 1BJ

Tel: 02380598454

E-mail: wp@soton.ac.uk

Dr Andrew Ridley

BSc MSc DIC PhD

Managing Director

Geotechnical Observations Limited

The Peter Vaughan Building 
9 Avro Way, Brooklands, Weybridge

Surrey KT13 0YF

Tel: 01932352040

E-mail: andrew@geo-observations.com

Derek J E Butcher

BEng CEng FICE

Civil Asset Engineer, Kent

Network Rail

General Offices

Waterloo Station

London SE1 8SW

E-mail: derek.butcher@networkrail.co.uk

Word count: 5408

Number of figures: 16

Number of tables: 2

Keywords: Monitoring; Vegetation; Embankments; Slopes; Pore pressures; Suction 


\section{Mechanical and hydrological impacts of tree removal on a clay fill railway embankment}

Smethurst J A, Briggs K M, Powrie W, Ridley A, Butcher D. J. E.

\section{Abstract}

Seasonal shrinkage and swelling of clay fill railway embankments can disturb the track geometry, resulting in train speed restrictions that disrupt normal operations. Such movements are exacerbated by vegetation, but reliable analytical descriptions of the effects of trees on embankment behaviour are not yet established. This paper presents and analyses the results of a field experiment, carried out on a heavily vegetated clay railway embankment to investigate quantitatively the influence of trees. After the first year of monitoring, the mature trees initially present on the upper two-thirds of the embankment slopes were removed. The field monitoring data are used to assess and understand the mechanisms of soil water content and pore water pressure changes before and after tree removal, and their influence on the vertical and lateral displacements of the embankment slopes. Removal of the vegetation stopped seasonal volume changes in the clay fill at the crest of the earthwork, but also resulted in the loss of the deep-seated suctions generally beneficial to embankment stability. The wider implications for the management of vegetation on embankment slopes are discussed.

\section{Introduction}

Many of the UK's railway embankments were constructed over 100 years ago, and not to modern geotechnical engineering standards. Soils, normally excavated from nearby areas of 
cut, were end-tipped to form embankments with little or no mechanical compaction (Skempton, 1996). Suctions generated within large clods or lumps of clay during excavation, and the behaviour of these stiff lumps as aggregates when tipped, allowed the formation of steep slopes. Large post-construction settlements, and slope collapse as the initial soil suctions dissipated, sometimes delayed the opening of the railway or caused significant problems in later years (Squire 1880; Skempton, 1996). Many embankments have continued to deteriorate, suffering serviceability problems and in some cases outright collapse (Andrei, 2000; O’Brien, 2007; Smethurst \& Powrie, 2007).

Until the 1960's, vegetation was heavily managed on many earthworks to reduce the risk of fire from steam locomotives. Following the end of steam on British Railways in 1968 most vegetation management ceased, allowing the establishment of mature trees on embankment slopes. Many native British species are deciduous, transpiring water drawn from the ground in the summer months and becoming dormant in winter. This causes drying of the soil during summer when transpiration exceeds rainfall, and wetting of the soil during the winter and spring when transpiration has ceased. Soil suctions generated by trees in summer can reach $1500 \mathrm{kPa}$ (Biddle, 1998), and substantial suctions have been measured in soil samples dug from tree covered embankments (O’Brien et al, 2004). Given that the total stress within embankment slopes is one or two orders of magnitude lower than the seasonal pore water pressure variation, trees have a dominant influence on the effective stress within an embankment and the associated deformation and behaviour (O'Brien et al, 2004).

Seasonal variations in water content and the resulting shrinkage and swelling of the soil causes problems for embankments constructed of high plasticity clay (Loveridge et al, 2010). Seasonal shrink/swell movements affect the line and level of the railway track, with the 
greatest track deformations occurring near mature trees (Andrei, 2000). For example, Scott (2006) measured vertical soil displacements at the crest of a high plasticity, London Clay fill embankment adjacent to a tree covered area of $50-55 \mathrm{~mm}$; an order of magnitude greater than for a grass covered area, where 5-8 $\mathrm{mm}$ was measured.

Tree roots can reach depths of up to $2-3 \mathrm{~m}$, depending on the availability of soil water and the mechanical ability of the roots to penetrate into the soil (Biddle, 1998). In contrast, grass roots remove water from a shallower zone of 0.5-1 m depth (Greenwood et al, 2001; Smethurst et al, 2012). Mature trees can develop persistent suctions that are maintained over a period of years or even decades because the rate of rainfall infiltration from the soil surface in the winter periods is insufficient for anything below the 1-2 $\mathrm{m}$ of soil nearest the surface to re-wet (Loveridge et al, 2010). In over-steep embankments, or embankments weakened by strain softening and vulnerable to progressive failure, these persistent suctions may be crucial in preventing deep-seated instability (O'Brien, 2007; Glendinning et al, 2009; Loveridge et al, 2010).

Seasonal shrink/swell displacements in some earthworks lead regularly to poor track quality, train speed restrictions, and ultimately to expensive track re-levelling work (Glendinning et al, 2009). To minimise these, asset owners such as Network Rail have been removing vegetation from the side slopes of the embankments. However, this may result in the loss of the persistent deep suctions and root reinforcement effects associated with trees, both of which help maintain slope stability. Observations of long-term pore water pressure variation and embankment displacement are required to assess and quantify the impact of tree removal, so that a managed approach to vegetation clearance and re-establishment may be developed that reduces both shrink/swell movements and the risk of deep seated instability. 
This paper presents monitoring data from field instrumentation installed within a London Clay railway embankment at Hawkwell, Essex. Temporary train speed restrictions had previously been imposed at this location on several occasions owing to track movements resulting from seasonal shrinkage and swelling. After the first year of monitoring, the mature trees initially present on the upper two-thirds of the embankment slopes were removed. The field monitoring data are used to assess and understand the mechanisms of soil water content and pore water pressure changes before and after tree removal, and their influence on the vertical and lateral displacements of the embankment slopes. The wider implications for the management of vegetation on embankment slopes are discussed, on the basis of the mechanical and hydrological data measured before and after tree removal at Hawkwell.

\section{Site description}

The instrumented site is on the Shenfield-Southend Victoria railway line near Hawkwell, north of Southend, Essex, UK (OS grid reference TQ856923; Fig. 1). The embankment was constructed around 1887. At the instrumented location it is $5.5 \mathrm{~m}$ high, and is constructed from a fill consisting mainly of London Clay excavated from adjacent areas of cut (Figs. 2 and 3). The in situ geology comprises superficial deposits of Head and Brickearth overlying London Clay. The natural ground profile dips gently to the south, so that the southern side of the embankment is slightly taller than the northern side. Slope angles average $23^{\circ}$ on the north side and $20^{\circ}$ on the south side, with the profiles flatter at the toe and steeper where ash and ballast are present at the crest. The instrumented section was located within a length of 
embankment vegetated with mature and semi-mature trees, consistently indicated by the Network Rail track recording vehicle (TRV) to be of particularly poor track quality.

A helicopter mounted LiDAR (Light Distance and Ranging) survey was carried out in December 2005 to obtain topographic contour plans and cross sections of the earthwork.

Geotechnical instrumentation as described below was installed during March 2006, mainly in vertical boreholes of $100 \mathrm{~mm}$ diameter. Some small, scrubby vegetation was removed to facilitate access by the drilling rig, but all mature trees were retained. U100 cores from all of the instrumentation holes were extracted and logged. The ground investigation showed that the north side slopes were covered in 0.5-1.1 m depth of granular material comprising a mixture of old ballast and ash (Fig. 3b). Granular material was not present on the south slope, apart from at the crest, although what may be old chalk rubble trench drains, up to $1.2 \mathrm{~m}$ deep, were identified in the ground investigation. Lankelma conducted a number of CPT tests along the embankment through the track bed, midway between the up and the down lines. The CPT results at the instrumented section, shown in Fig. 4, indicate over a metre of ballast overlying ash, the clay fill and the in situ London Clay. The boundary between the clay fill and the in situ clay is defined by the sandy layer identified just below $7 \mathrm{~m}$ depth.

Both the embankment fill and the in situ London Clay beneath the embankment are weathered, as evidenced by their brown-yellow colouring. The clay fill contains occasional fine to coarse gravels, small pockets of ash and sand, and fragments of brick. Disturbed samples of the intact London Clay and clay fill were used to determine liquid and plastic limits (Fig. 5). Generally, the London Clay is of higher plasticity in the east of the London basin than the west (Burnett \& Fookes, 1974); at the study site, the in situ London Clay was 
of very high plasticity. The embankment fill was classified as intermediate to very high plasticity.

Trees were removed from the upper two-thirds of the slopes over the $20 \mathrm{~m}$ long instrumented section during March 2007, as shown in Fig. 3. The felled trees were mainly oak (Quercus robur), with some ash (Fraxinus excelsior). The National House Building Council (NHBC) guidance on building near trees (NHBC, 2007) classifies oak as being of high water demand, and ash of moderate water demand. Further tree clearance occurred in March 2010, along the full length of the embankment. All of the trees adjacent to the instrumented section were felled, leaving only two semi-mature trees close to the ditch at the toe of the south facing slope. Between March 2007 and the second tree clearance in March 2010, small saplings and other scrubby vegetation became re-established on the slopes.

\section{Instrumentation}

Instrumentation was installed broadly in three groups on each side of the embankment, at the crest, midslope and towards the toe, as shown in Fig. 3. Instruments included deep standpipe piezometers, flushable piezometers, neutron probe access tubes, inclinometer tubes and magnet extensometers (Table 1). A datalogged tipping bucket rain gauge was installed on the north slope to measure rainfall at the site.

Standpipe piezometers were installed on each side of the embankment from the crest to a depth of about $9.0 \mathrm{~m}$ below ground level, and at the toe to a depth of $4.0 \mathrm{~m}$ on the south side and $6.0 \mathrm{~m}$ on the north. The tips were packed in sand, with the remainder of the installation 
grouted. The standpipes were dipped during visits to the site. Geo-piezometers were installed by Geotechnical Observations Ltd. at both shallow and deeper levels within the embankment (Fig. 3b). These can measure suctions up to about $90 \mathrm{kPa}$ in addition to positive pore pressures, and flushing tubes allowing de-aired water to be circulated through the device to remove air. The Geo-piezometer and its installation technique are described by Ridley et al (2003a, 2003b).

Four $50 \mathrm{~mm}$ diameter aluminium neutron probe access tubes were installed at the crest and midslope on each side of the embankment to a depth of approximately $3.5 \mathrm{~m}$. As the soil must be in intimate contact with the access tube, $50 \mathrm{~mm}$ diameter holes were created using a window sample tube, inserted using the drilling rig. Neutron probe readings were taken using the access tubes during monthly visits to the site. The calibration curves for conversion of radioactive count to soil water content were obtained for both neutron probes used (see Table 1) by taking gravimetric samples from the London Clay at a site near Newbury (Smethurst et $a l$, 2006). Given the heterogeneous nature of the embankment and variation of neutron probe calibration curves with soil type (Bell, 1987), the measurements of soil water content will not be exact. The technique does however provide detailed profiles of water content change that allow root water abstraction and infiltration effects to be observed.

Inclinometer tubes and magnet extensometers were installed by Geotechnical Observations Ltd. at both the crest and mid-slope, to depths of between 8 and $10 \mathrm{~m}$ below ground level into the underlying London Clay. Magnets were spaced down the extensometers at intervals of approximately $0.25 \mathrm{~m}$ within the clay fill and $1.0 \mathrm{~m}$ in the intact London Clay. Vertical displacements were measured relative to the lowest magnet, which was assumed not to move. Readings of both sets of instruments were taken monthly. Measurements of magnet depth 
were repeatable to within $+/-1 \mathrm{~mm}$. Inclinometer readings were interpreted assuming the base of the tube to be fixed, and the repeatability of readings was found to be better than $+/$ $1.0 \mathrm{~mm}$ over the full depth of the installations.

\section{Rainfall}

Annual rainfall totals before and during the monitoring period are shown in Fig. 6(a) for London Heathrow, $80 \mathrm{~km}$ from the Hawkwell embankment site. These data show that the years preceding the monitoring period (2003 and 2005) were drier than the London Heathrow 1961-1990 long term average (LTA). An absence particularly of summer rainfall may cause significant soil drying and development of pore water suctions (Smethurst et al., 2012).

Fig. 6(b) compares monthly rainfall totals measured at Hawkwell between April 2006 and March 2011 with the London Heathrow 1961-1990 long term average (LTA). The data show wetter than average summers in 2007 and 2008 (immediately after tree felling), with a drier than average autumn and winter in between.

Smethurst et al (2012), in analysing rainfall for Newbury, Berkshire, found that 2007 and 2008 were amongst the five wettest summers within a 42 year run of measurements, while 2005 was the driest year.

\section{Measured displacements}


Shrinkage of the embankment was measured during the summer of 2006 , when trees were present on the embankment slopes. In the summers of 2007 and 2008 following tree removal, heave of the embankment was measured. Greater heave occurred on the north side of the embankment, where more trees had been felled (Fig. 3a). The smallest vertical displacements were measured at the borehole furthest from the trees, at the crest of the south facing slope. The maximum vertical and lateral displacements are summarised in Table 2.

Figs. 7 and 8 show extensometer and inclinometer data plotted against time for installations at the crest (north slope) and midslope (south slope) of the embankment. All measurement depths shown are from ground level at the top of the installation.

At the north crest of the embankment (Fig. 7), $40 \mathrm{~mm}$ of vertical shrinkage occurred in the summer of 2006 when trees were present on the embankment slope. This was recovered by swelling over the ensuing autumn and winter period. Following removal of the trees in March 2007, continual swelling occurred through to the end of the monitoring period, with substantial upward and outward displacements measured. The largest vertical and lateral displacements occurred between $0 \mathrm{~m}$ and $3.5 \mathrm{~m}$ depth, with smaller displacements at greater depths. Swelling was particularly pronounced over the spring of 2008 , which was very wet and followed a wet summer (Fig. 6b); some reversal of movement (shrinkage) was measured in the summer of 2009, which was drier than the long term average.

At the south midslope of the embankment (Fig. 8), shrinkage occurred throughout the soil profile in the summer of 2006 and was largely recovered in the following winter and spring. Vertical seasonal shrink/swell movements continued between $0 \mathrm{~m}$ and $1.63 \mathrm{~m}$ depth in subsequent years with a general trend of upward heave, while at greater depths some small 
( $<10 \mathrm{~mm}$ in total) ongoing upward vertical displacements were measured. Significant lateral outward displacements, occurring between $0 \mathrm{~m}$ and $1.95 \mathrm{~m}$ depth, began in March 2009 almost 2 years after the trees had been removed from the slope.

Swelling occurred at the north crest immediately after tree removal (Fig. 7), while swelling at the south midslope was delayed and of smaller magnitude. The south midslope measurements may have been influenced by the trees remaining at the toe of the slope, which continued to create a clear seasonal variation in the readings between $0 \mathrm{~m}$ and $2 \mathrm{~m}$ depth.

The displacement measurements show that tree felling on the upper part of the earthwork substantially reduced seasonal shrink/swell movements adjacent to the track; soil swelling then took place over several years.

\section{Measurements of soil water content and pore water pressure}

Changes in soil water content and pore water pressure due to tree removal

Tree felling at Hawkwell altered patterns of soil wetting and drying, causing a general increase in soil water content and pore water pressures within the embankment.

Figs. 9 and 10 show profiles of volumetric water content $(\theta=$ volume water/total volume) with depth measured at the end of winter (March / April) throughout the monitoring period. The driest profiles were measured during March and April 2007, when trees were present on the embankment slope. Following tree removal, higher volumetric water contents were measured, approaching saturation at $\theta \sim 45 \%$ (which is consistent with other in situ 
measurements for London Clay: Croney, 1977; Biddle, 1998; Smethurst et al, 2006). On the north side of the embankment (Fig. 9), the volumetric water content increased from a dry profile to a near-saturated profile between April 2007 and April 2008, consistent with the rapid swelling shown in Fig. 7(a). On the south side of the embankment (Fig. 10), considerable, but not complete, rewetting of the soil profile occurred in March 2009, one year later than on the north side. This is consistent with the relative patterns of vertical and lateral displacements (Fig. 8).

Fig. 11 shows a sequence of neutron probe readings for the north crest after tree removal, as the embankment fill reached saturation between $2.0 \mathrm{~m}$ and $3.75 \mathrm{~m}$ depth. The plot shows a sharp transition from the dry soil at approximately $35 \%$ water content to near saturation at $45 \%$ volumetric water content, which moves progressively downward over time. This is consistent with classic wetting front infiltration into an unsaturated soil (e.g. Gavin \& Xue, 2008). In reality, the wetting front might be sharper with the transition from dry to wet soil occurring over a smaller depth than shown, because the neutron probe measures the average water content within a sphere of soil of radius $\sim 140 \mathrm{~mm}$ and is therefore unable to define the wetting front more precisely.

Pore water pressures measured at the north crest of the embankment at depths of $2.8 \mathrm{~m}, 3.7 \mathrm{~m}$ and $5.8 \mathrm{~m}$ are shown in Fig. 12. The apparent sharp returns to positive pore pressure followed by a gradual recovery of the reading occur as the instrument is flushed to remove any buildup of air. Indicative trend lines ignoring these spikes are plotted over the raw piezometer data; these show genuine sharp increases in pore water pressure at $2.8 \mathrm{~m}$ and $3.7 \mathrm{~m}$ depth between December 2007 and the start of April 2008. At $5.8 \mathrm{~m}$ depth, a more gradual increase in pore water pressure is evident up to the summer of 2008. 
Comparison of the piezometer and neutron probe measurements for the north crest show that the true sharp increases in pore water pressure coincide with the soil water content reaching saturation at that depth (Fig. 11). The soil profile from $2.8 \mathrm{~m}$ to $3.7 \mathrm{~m}$ depth reaches saturation between November 2007 and April 2008 (Fig. 11), coinciding with the period in which the pore water pressures also increase sharply (Fig. 12). The rapid change in pore water pressure corresponds to the progression of a sharp wetting front into the soil, above which the soil is saturated. The water content profiles measured after May 2008 show that the soil then remained saturated at $2.8 \mathrm{~m}$ and $3.7 \mathrm{~m}$ depth, consistent with the continuous measurement of pore water pressures close to $0 \mathrm{kPa}$ over the same period.

\section{Seasonal patterns of soil drying before and after tree removal}

Biddle $(1983,1998)$ showed that, for some tree species, a zone of persistently dry soil (i.e., a persistent soil moisture deficit) can develop below the depth that is seasonally affected. End of winter (March) and end of summer (September) volumetric water content profiles before and after tree removal are compared in Fig. 13. The volumetric water content varied seasonally to a depth of between $1.5 \mathrm{~m}$ and $2.25 \mathrm{~m}$ when trees were present on the upper part of the embankment, but remained persistently dry at greater depths.

Comparison of the end of winter soil profiles before and after tree removal shows that the volumetric water content within the persistently dry zone increased towards saturation following tree removal (Fig. 13). Seasonal volumetric water content variations then occurred, closer to soil saturation, to a depth of between $2 \mathrm{~m}$ and $2.5 \mathrm{~m}$. It is easier for plants to extract water closer to the saturation point, when water is present in larger pores in the fabric of the 
fill material. As the soil dries, plants would need to generate substantial suctions to remove water from intact peds (lumps) of clay (Smethurst et al, 2012). This is shown in the profiles of pore water pressure before and after tree removal (Fig. 14). When trees were present on the embankment slopes pore water pressures varied seasonally between 0 to $-20 \mathrm{kPa}$ at the end of winter and $-80 \mathrm{kPa}$ at the end of summer. At the end of the summer of 2009,18 months after tree removal, pore water pressures had increased to around $0 \mathrm{kPa}$ and large soil suctions were not generated by the seasonal change in water content.

Standpipe piezometers installed to 5-6 $\mathrm{m}$ below the clay fill/in situ London Clay interface remained dry for most of the monitoring period, indicating a heavily depressed water table below the embankment. A zone of persistent soil moisture deficit of such a depth was likely generated by tree water abstraction over a deep rooting zone (up to $3 \mathrm{~m}$ ), together with limited water infiltration due to low rainfall in the years preceding the monitoring period (the years 2003 and 2005 were below the LTA; Fig. 6a). However, it should be noted that Essex is one of the warmest and driest parts of the country, such that over a typical year the actual evapotranspiration from mature vegetation will be almost the same as the rainfall (Clarke \& Smethurst, 2010). These climatic conditions are ideal for the development of a persistent soil moisture deficit.

The soil water content profile within the embankment four years after tree removal was close to saturation. This could allow positive (possibly hydrostatic) pore water pressures to develop during periods of heavy rainfall preceded by a prolonged wetter period (Briggs et al, 2013a), with the potential to reduce the stability of the earthwork. 


\section{Linking climate to soil water content and displacements}

\section{Climate and soil water content}

The soil moisture deficit is defined as the amount of water (in $\mathrm{mm}$ ) required to bring the soil to "field capacity", the maximum water content that the soil is able to hold against gravity in conditions of free downward drainage. The measured soil moisture deficit, $\mathrm{SMD}_{\mathrm{m}}$, over a depth $H$ was calculated at monthly intervals from the sum of the neutron probe measurements of volumetric water content $\theta$, each taken as representative of one of $n$ soil layers of depth $h$ :

$\mathrm{SMD}_{\mathrm{m}}=\sum_{i}^{n} h_{i}\left(\theta_{F C}-\theta_{i}\right)$

where $\theta_{i}$ is the measured volumetric water content within each layer, $\theta_{F C}$ is the volumetric water content of the soil at field capacity, and $h_{i}$ is the depth over which $\theta_{i}$ is assumed to apply. Volumetric water contents at field capacity $\left(\theta_{F C}\right)$ of $35 \%$ and $45 \%$, corresponding with the wettest soil profiles measured (Figs. $9 \& 10$ ), were assumed for the ash/ballast and clay fill respectively. The depth, $\mathrm{H}$, was assumed to extend from the soil surface to the limit of the neutron probe measurements at about $3 \mathrm{~m}$. The piezometer data indicate soil drying to a depth greater than $3 \mathrm{~m}$ (Fig. 14); thus the calculated value is likely to be an underestimate of the actual soil moisture deficit.

Fig. 14 compares $\mathrm{SMD}_{\mathrm{m}}$ with the MORECS (Meteorological Office Rainfall and Evaporation Calculation System) SMD, calculated by the Meteorological Office (2012) for deciduous tree cover in Southend (MORECS square 163). The MORECS SMD indicates the cumulative balance of soil wetting and drying due to rainfall and evapotranspiration, and is calculated from daily weather data published for $40 \mathrm{~km} \times 40 \mathrm{~km}$ squares covering the UK (Hough et al., 
1997). Both the measured $\left(\mathrm{SMD}_{\mathrm{m}}\right)$ and the MORECS soil moisture deficits indicate soil wetting during the winter months (decreasing SMD) and drying during the summer months (increasing $\mathrm{SMD}$ ). $\mathrm{SMD}_{\mathrm{m}}$ following tree removal on the south midslope varied from slightly drier to slightly wetter than the MORECS SMD, as the persistent SMD created by the trees was gradually lost. However, the south midslope continued to be influenced by trees remaining at the toe of the slope, as shown by the seasonal $\mathrm{SMD}_{\mathrm{m}}$ variation.

The removal of the trees from the embankment slopes altered the surface water balance, resulting in reduced evapotranspiration, hence a net annual infiltration and a reduction in the SMD. This is likely to have been aided by two reasonably wet years (2007 and 2008) following tree removal (Fig. 6a). Recovery of the persistent soil moisture deficit was more rapid on the north side of the earthwork than the south side (Figs. 9, 10 and 15). It is likely that the granular ash and ballast on the north facing slope, which is reasonably free draining (Briggs et al, 2013a), enabled more rapid water infiltration into the earthwork than on the south facing slope, where the clay fill extends to the surface. Being a northern hemisphere site, the south facing slope is also exposed to greater solar radiation than the relatively shaded north facing slope, increasing plant transpiration and the evaporation of surface water.

\section{Water content and displacements}

Fig. 16 compares the vertical displacements at approximately $1 \mathrm{~m}$ depth at the midslope of the embankment measured using magnet extensometers (as shown in Fig. 8a) with those calculated from the changes in volumetric water content measured by the neutron probe, assuming isotropic shrinkage of a zone of soil between $1 \mathrm{~m}$ and $3 \mathrm{~m}$ depth. This ignores desaturation of the soil in both the structural and residual phases of soil drying (Biddle, 
1998), and may therefore tend to overestimate the soil volume change. The wetting and drying phases calculated from the neutron probe data correspond to the measured shrinking and swelling phases of the soil. The soil swelling due to water infiltration is indeed overestimated, while shrinkage is underestimated. This could be because the depth of soil drying (and hence shrinkage) is beyond the extent of the neutron probe measurements (i.e. below $3 \mathrm{~m}$ depth, Fig. 10b), and/or because shrinkage manifests disproportionately as vertical settlement rather than lateral contraction and tensile cracking (Driscoll, 1983).

\section{Discussion and implications for practice}

Tree covered clay fill embankments of low permeability in areas of low annual rainfall are likely to maintain a year-round moisture deficit and associated pore water suctions. Seasonal variations in soil water content and pore pressure within the tree rooting zone, between $0 \mathrm{~m}$ and up to $3 \mathrm{~m}$ depth, can cause significant $(\sim 40 \mathrm{~mm})$ seasonal shrink/swell movements to occur, as has been measured at Hawkwell and in other London Clay fill embankments (Andrei, 2000; Scott, 2006; Briggs et al, 2013b).

Removal of the trees from the upper two-thirds of the embankment slope reduced seasonal shrink/swell displacements at the crest of the earthwork. Within two to four years the persistent moisture deficit and pore water suctions that had been established by the trees prior to felling had been eliminated by infiltrating water, and a new pattern of seasonal variation closer to the clay saturation point was established. This variation does not seem to cause the same extent of volume change in the clay. This may be because the water in the clay fill that is close to saturation resides in larger pores, which fill with air as the plants remove water. 
While the trees left at the toe on the south side of Hawkwell embankment may have delayed rewetting of the midslope, they were unable to prevent the eventual near total loss of soil suctions in this location. The higher than average rainfall in 2007 and 2008 may have contributed to the fairly rapid rate at which wetting occurred. No instrumentation, beyond deeper standpipe piezometers, was installed at the toes of the slopes, and it not possible to confirm whether the trees left at the toe were able to maintain residual moisture deficit/suctions that would benefit stability.

The study was not of sufficient duration for the vegetation re-growth to develop a permanent moisture deficit, as had previously been established by the mature tree cover. In 2009, after three years re-growth, measured pore pressures remained slightly negative except during winter/spring periods, when some measurements became slightly positive (up to approximately $10 \mathrm{kPa}$ ). Pore water pressures have remained below hydrostatic. However, a largely saturated clay embankment with limited water storage capacity is vulnerable to pore water pressure increases towards hydrostatic values during periods of prolonged heavy rainfall (Briggs et al, 2013a); these represent a more onerous condition for slope stability. Inclinometer measurements (not shown) suggested that a shallow failure may have started to form on the midslope of the north side of the embankment by the end of the monitoring period, although this did not extend to the crest.

Tree removal within the instrumented section largely eliminated seasonal shrink/swell at the crest of the embankment in 2007 , although some swelling continued through to the end of the monitoring period in April 2011. Network Rail therefore removed most of the remaining vegetation on Hawkwell embankment in early 2010. Inclinometer tubes and survey points were installed along the full length of the earthwork shortly after vegetation removal to 
monitor ground movements, and a traffic light system was devised to aid decision making on actions that may be required to prevent deterioration or failure of the earthwork (Smethurst, 2010).

It is recommended that vegetation clearance is undertaken cautiously. This study shows that if trees are removed from the upper two thirds of the embankment, any permanent deficit or soil suction below the cleared part of the slopes may be lost before new vegetation becomes established. A reduction in shrink/swell displacements without substantially increasing the risk of slope instability may require a more limited vegetation clearance than that at Hawkwell; for example, the removal only of high water demand tree species within a defined distance of influence (Briggs et al., 2013b). The risk of slope failure due to tree removal can be assessed using established stability analyses, informed by the scenarios of pore water pressure change and persistent suctions at depth presented in this paper. Site-specific risks to slope stability should also be considered, including but not limited to the permeability and volume change potential of the clay fill and underlying foundation, and the influence of tree root reinforcement and tree induced strain softening of the soil (Glendinning et al, 2009). A strategy for monitoring and managing instability should be in place before vegetation removal commences.

\section{Conclusions}

a) The influence of climate and vegetation on seasonal variations in the soil water content, pore water pressures and lateral and vertical displacements of a clay fill embankment has 
been investigated quantitatively by means of detailed field measurements. Soil drying and shrinkage were measured during summer and autumn, and soil wetting and swelling during winter and spring. The depth and magnitude of these seasonal changes were influenced by the presence and later removal of mature trees on the embankment slope.

b) The mature trees initially on the embankment slopes had established a substantial persistent soil moisture deficit in the clay earthwork and its foundation, which was maintained below a depth of approximately $2 \mathrm{~m}$ during the winter months. Above $2 \mathrm{~m}$ depth, seasonal variations in soil water content and pore water pressure resulted in substantial seasonal vertical movements of up to $40 \mathrm{~mm}$ at the crest of the embankment.

c) Removal of the mature trees from the upper part of the embankment altered the surface water balance, reducing evapotranspiration and increasing infiltration, causing the earthwork gradually to re-wet. Water contents and pore water pressures within the embankment increased through infiltration from the surface, and the persistent soil moisture deficit that had been established by the trees was lost. This caused the clay fill to swell and the embankment slope to heave over a period of at least four years, although seasonal variations in surface movement reduced substantially.

d) The mechanism of soil drying by vegetation differed from that of soil wetting due to rainfall infiltration. Rainfall was found to infiltrate from the soil surface via a classic wetting front. Shallow plant (shrub) roots and mature tree roots remove water from below the surface, creating a drying profile throughout the root zone, with the greatest drying occurring at the soil surface and reducing with depth. Mature trees have roots that extend 
to greater depth, are able to generate larger suctions and draw water from deeper within the embankment and its foundation.

e) Three years after tree removal, seasonal cycles of wetting and drying were still occurring at shallow (up to $2.5 \mathrm{~m}$ ) depths, but within a range of soil water contents closer to a nearsaturated profile. This significantly reduced the seasonal variation in pore water pressures, to between -20 and $10 \mathrm{kPa}$. While pore water pressures remained below hydrostatic, the water storage capacity of the soil was reduced following tree removal, increasing the risk of hydrostatic pore water pressures and hence slope instability during periods of prolonged wet weather.

f) Tree removal within the instrumented section was effective in substantially reducing seasonal shrink/swell movements at the crest of the embankment, although the soil moisture deficit and suctions that aid slope stability were lost as the embankment rewet. A balance between maintaining stability and reducing seasonal displacements may require a more limited or selective vegetation clearance than was carried out in this case, such as the managed removal of high water demand trees.

\section{Acknowledgements}

The installation of instrumentation and monitoring of the Hawkwell embankment was funded by Network Rail as part of ongoing research into the performance of aging earthworks. Anna Pearson and Chris Martin of Arup were involved with specifying and managing the site investigation, and initial management and interpretation of monitoring data. The final year of 
readings carried out by the University of Southampton was supported by EPSRC grants numbers EP/F063482 and EP/H044949.

\section{Notation}

$\theta \quad$ Volumetric water content

$\theta_{i} \quad$ Volumetric water content measured at a particular depth

$\theta_{F C} \quad$ Volumetric water content at field capacity

$h_{i} \quad$ The depth of soil profile over which $\theta_{i}$ applies

$H \quad$ The total depth of neutron probe measurements

$n \quad$ Number of readings

$\mathrm{SMD}_{\mathrm{m}} \quad$ Measured soil moisture deficit

\section{References}

Andrei, A. (2000). Embankment stabilisation works between Rayners Lane and South Harrow Underground stations. Ground Engineering, 33, No. 1, 24-26.

Arup (2007). Geotechnical interpretive report, Magnolia Road embankment. Arup, London. 
Bell, J. P. (1987). Neutron probe practice, Institute of Hydrology report 19, 3rd edition. http://www.ceh.ac.uk/products/publications/documents/IH19NEUTRONPROBEPRACTICE. pdf

Biddle, P. G. (1983). Patterns of soil drying and moisture deficit in the vicinity of trees on clay soils. Géotechnique 33, No. 2, 107-126.

Biddle, P. G. (1998). Tree root damage to buildings. Wantage: Willowmead Publishing.

Briggs, K. M., Smethurst, J. A., Powrie, W. \& O’Brien, A. S. (2013a). Wet winter pore pressures in railway embankments. Proceedings of the Institution of Civil Engineers Geotechnical Engineering. 166, GE5, 451-465.

Briggs, K. M., Smethurst, J. A., Powrie, W., O’Brien, A. S. \& Butcher, D. J. E. (2013b). Managing the extent of tree removal from railway earthwork slopes. Ecological Engineering. 61, Part C, 690-696.

Burnett, A. \& Fookes, P. (1974). A regional engineering geological study of the London Clay in the London and Hampshire basins. Quarterly Journal of Engineering Geology, 7, 257-295.

Clarke, D. \& Smethurst, J. A. (2010). Effects of climate change on cycles of wetting and drying in engineered clay slopes in England. Quarterly Journal of Engineering Geology and Hydrogeology, 43 (4) 473-486. 
Croney, D. (1977). The design and performance of road pavements. London: Her Majesty's Stationery Office.

Driscoll, R. (1983). The influence of vegetation on the swelling and shrinking of clay soils in Britain. Géotechnique, 33 (2), 93-105.

Gavin, K. \& Xue, J. F. (2008). A simple method to analyze infiltration into unsaturated soil slopes. Computers and Geotechnics, 35 (2):223-230.

Glendinning, S., Loveridge, F. A., Starr-Keddle, R. E., Bransby, M. F. \& Hughes, P. N. (2009). Role of vegetation in sustainability of infrastructure slopes. Proceedings of the Institution of Civil Engineers - Engineering Sustainability. 162, ES2, 101-110.

Greenwood, J. R., Vickers, A. W., Morgan, R. P. C., Coppin, N. J. \& Norris, J. E. (2001). Bioengineering: the Longham Wood Cutting field trial, CIRIA Project Report 81. London: Construction Industry Research and Information Association.

Hough, M. N., Palmer, S. G. , Lee, M. J., Barrie., I. A., and Weir A. (1997). The Meteorological Office rainfall and evaporation calculation system: MORECS Version 2.0 (1995). Meteorological Office, Bracknell.

Loveridge, F. A., Spink, T. W., O’Brien, A. S., Briggs, K. M. \& Butcher, D. (2010). The impact of climate and climate change on UK infrastructure slopes. Quarterly Journal of Engineering Geology and Hydrogeology. 43 (4), 461-472. 
Met Office (2012). General weather and atmospheric data. [online]. Available at: http://www.metoffice.gov.uk/services/industry/data/general

NHBC (2007). National House Building Council Standards, Chapter 4.2, Building near trees. NHBC, Milton Keynes.

O’Brien, A.S., Ellis, E.A., \& Russell, D. (2004). Old railway embankment fill - laboratory experiments, numerical modelling and field behaviour. In: Advances in Geotechnical Engineering: Proceedings of the Skempton Conference, London, Volume 2 (pp. 911-921). London: Thomas Telford.

O’Brien, A. S. (2007). Rehabilitation of urban railway - investigation, analysis, and stabilisation. In: Cuellar, V., Dapena, E. et al (eds) Proceedings of the $14^{\text {th }}$ International Conference on Soil Mechanics and Geotechnical Engineering, Madrid, Vol. 1, Millpress Science Publishers, Rotterdam, 125-143.

Ridley A. M., Dineen, K., Burland J. B. \& Vaughan P. R. (2003a). Soil matrix suction: some examples of its measurement and application in geotechnical engineering. Géotechnique 53 (2), 241-253.

Ridley A. M., Brady K. C. and Vaughan P. R. (2003b). Field measurement of pore water pressures. TRL Report 555. Transport Research Laboratory, Crowthorne, Berks. 
Scott, J.M. (2006). Influence of vegetation on the performance of railway embankments. In: Szavits-Nossan, V. (ed.) Proceedings of the 17th European, Young Geotechnical Engineers Conference, Zagreb, 2006. Croatian Geotechnical Society, Velika Gorica, Croatia, 101-112.

Skempton, A. W. (1996). Embankments and cuttings on the early railway. Construction History, 11, 33-49.

Smethurst, J. A. (2010). Tracking changes. Ground Engineering. July, 12-14.

Smethurst, J. A., Clarke, D. \& Powrie, W. (2006). Seasonal changes in pore water pressure in a grass covered cut slope in London Clay. Géotechnique, 56 (8), 523-537.

Smethurst, J. A., Clarke, D. \& Powrie, W. (2012). Factors controlling the seasonal variation in soil water content and pore water pressures within a lightly vegetated clay slope.

Géotechnique, 62(5), 429-446.

Smethurst, J. A. \& Powrie, W. (2007). Monitoring and analysis of the bending behaviour of discrete piles used to stabilise a railway embankment. Géotechnique, 57 (8), 663-677.

Squire, J. B. (1880). Earthworks slips in the cuttings and embankments of various railways, with their causes and modes of treatment. Minutes of the Proceedings of the Institution of Civil Engineers, Vol. 62, Part 4, 272-287.

Table 1: Summary of instrumentation and monitoring equipment

\begin{tabular}{|l|l|l|l|l}
\hline Measurement & Instrument & Quantity and & Measuring & Source \\
\hline
\end{tabular}




\begin{tabular}{|c|c|c|c|c|}
\hline & type & depth & range/resolution & \\
\hline $\begin{array}{l}\text { Soil water } \\
\text { content }\end{array}$ & Neutron probe & $\begin{array}{l}4 \text { no. Access } \\
\text { tubes, to a depth } \\
\text { of } 3.5 \mathrm{~m}\end{array}$ & $\begin{array}{l}\text { Volumetric } \\
\text { water content, 0- } \\
50 \%\end{array}$ & $\begin{array}{l}\text { Wallingford probe } \\
\text { manufactured by } \\
\text { Didcot } \\
\text { Instruments, UK; } \\
\text { 503DR } \\
\text { Hydroprobe } \\
\text { manufactured by } \\
\text { CPN Inc., USA }\end{array}$ \\
\hline Soil suction & $\begin{array}{l}\text { Flushable } \\
\text { piezometer }\end{array}$ & $\begin{array}{l}14 \text { no. to depths } \\
\text { between } 1.3 \mathrm{~m} \\
\text { and } 5.8 \mathrm{~m}\end{array}$ & $\begin{array}{l}\text { Pore pressure } \\
\text { between } 300 \mathrm{kPa} \\
\text { and }-90 \mathrm{kPa}\end{array}$ & $\begin{array}{l}\text { Geotechnical } \\
\text { Observations Ltd, } \\
\text { Weybridge, UK }\end{array}$ \\
\hline $\begin{array}{l}\text { Pore water } \\
\text { pressure }\end{array}$ & $\begin{array}{l}\text { Standpipe } \\
\text { piezometer }\end{array}$ & $\begin{array}{l}4 \text { no. to depths } \\
\text { of } 4.1,5.7,8.5 \\
\text { and } 10.7 \mathrm{~m} \\
\end{array}$ & $\begin{array}{l}\text { Pore pressure } \\
\text { greater than } 0 \\
\mathrm{kPa}\end{array}$ & $\begin{array}{l}\text { Geotechnical } \\
\text { Observations Ltd, } \\
\text { Weybridge, UK }\end{array}$ \\
\hline $\begin{array}{l}\text { Lateral } \\
\text { displacement }\end{array}$ & Inclinometer & $\begin{array}{l}4 \text { no. to depths } \\
\text { of } 6.95,8.15 \text {, } \\
8.23 \text { and } 9.5 \mathrm{~m} \\
\end{array}$ & $\begin{array}{l}\text { Resolution of } 0.1 \\
\text { mm per } 0.5 \mathrm{~m} \\
\text { depth of tube }\end{array}$ & $\begin{array}{l}\text { Geotechnical } \\
\text { Observations Ltd, } \\
\text { Weybridge, UK }\end{array}$ \\
\hline $\begin{array}{l}\text { Vertical } \\
\text { displacement }\end{array}$ & $\begin{array}{l}\text { Magnet } \\
\text { extensometer }\end{array}$ & $\begin{array}{l}4 \text { no. to depths } \\
\text { of } 7.12,8.82 \text {, } \\
8.67 \text { and } 8.67 \mathrm{~m} \\
\end{array}$ & $\begin{array}{l}\text { Tape } \\
\text { measurement at } \\
1 \mathrm{~mm} \text { resolution }\end{array}$ & $\begin{array}{l}\text { Geotechnical } \\
\text { Observations Ltd, } \\
\text { Weybridge, UK }\end{array}$ \\
\hline Rainfall & $\begin{array}{l}\text { Tipping bucket } \\
\text { rain gauge }\end{array}$ & North slope & $\begin{array}{l}\text { Resolution of } 0.2 \\
\mathrm{~mm}\end{array}$ & $\begin{array}{l}\text { Delta-T Devices } \\
\text { Ltd, Cambridge, } \\
\text { UK }\end{array}$ \\
\hline
\end{tabular}

Table 2: Summary of maximum displacements measured between May 2006 and March 2011

\begin{tabular}{|l|l|l|l|}
\hline Slope position & $\begin{array}{l}\text { Maximum soil } \\
\text { settlement before } \\
\text { tree removal in } \\
\text { March 2007 }\end{array}$ & $\begin{array}{l}\text { Maximum } \\
\text { vertical soil } \\
\text { heave }\end{array}$ & $\begin{array}{l}\text { Maximum } \\
\text { horizontal soil } \\
\text { heave }\end{array}$ \\
\hline South midslope & $33 \mathrm{~mm}(0.67 \mathrm{~m})$ & $42 \mathrm{~mm}(1.08 \mathrm{~m})$ & $28.6 \mathrm{~mm}(0.45 \mathrm{~m})$ \\
\hline South crest & $5.5 \mathrm{~mm}(2.16 \mathrm{~m})$ & $3 \mathrm{~mm}(2.60 \mathrm{~m})$ & $29 \mathrm{~mm}(0.00 \mathrm{~m})$ \\
\hline North crest & $39 \mathrm{~mm}(1.14 \mathrm{~m})$ & $68 \mathrm{~mm}(1.14 \mathrm{~m})$ & $52 \mathrm{~mm}(0.23 \mathrm{~m})$ \\
\hline North midslope & $21 \mathrm{~mm}(0.62 \mathrm{~m})$ & $58.5 \mathrm{~mm}(0.62 \mathrm{~m})$ & $63 \mathrm{~mm}(0.15 \mathrm{~m})$ \\
\hline
\end{tabular}

Note: The depth of the inclinometer/extensometer magnet associated with the measurement is shown in brackets. 


\section{Figure captions}

Figure 1: Location of the instrumented site

Figure 2: Photograph showing the south side of the embankment in March 2010, shortly after the second vegetation clearance.

Figure 3: Location of instrumentation at Hawkwell embankment, shown (a) in plan; and (b) in cross section. In (b), the symbols mark the maximum depth of each installation, and tree form and height are not drawn to scale. Redrawn from Arup (2007).

Figure 4: CPT data taken through the centre of the embankment midway between the up and down lines.

Figure 5: Plasticity of in situ London Clay and embankment fill

Figure 6: (a) Annual rainfall totals measured at London Heathrow (2000-2011); (b) Monthly rainfall totals measured at Hawkwell over the monitoring period.

Figure 7: North crest installations: (a) vertical extensometer displacements plotted relative to initial magnet positions in April 2006; and (b) horizontal inclinometer displacements plotted relative to initial positions in April 2006.

Figure 8: South midslope installations: (a) vertical extensometer displacements plotted relative to initial magnet positions in April 2006; and (b) horizontal inclinometer displacements plotted relative to initial positions in April 2006.

Figure 9: End of winter (March - April) volumetric water contents, north embankment slope: (a) crest; (b) midslope.

Figure 10: End of winter (March - April) volumetric water contents, south embankment slope: (a) crest; (b) midslope.

Figure 11: North crest volumetric water content variation from May 2007 to May 2008, with initial and final measurements shown for comparison

Figure 12: North crest piezometer measurements at $2.8 \mathrm{~m}, 3.7 \mathrm{~m}$ and $5.8 \mathrm{~m}$ depth, with indicative trend lines for pore water pressure shown. The spikes to positive pore pressures indicate piezometer flushing taking place, after which the readings slowly come back to equilibrium with pore water pressures in the soil.

Figure 13: End of winter (March) and end of summer (September) volumetric water content before and after tree removal, at the midslope of the: (a) south slope; (b) north slope.

Figure 14: End of winter (March) and end of summer (September) pore water pressures before and after tree removal: (a) crest of both north and south slopes; (b) midslope of both north and south slopes. 
Figure 15: Comparison of soil moisture deficit $\left(\mathrm{SMD}_{\mathrm{m}}\right)$ measured at the embankment midslope with the MORECS SMD calculated from climate data (Met Office, 2012). The calculated $\mathrm{SMD}_{\mathrm{m}}$ for the north midslope stops in December 2009 as the neutron probe access tube was bent by ground movements and could no longer be read to the full depth.

Figure 16: Comparison of measured and calculated vertical displacement at $1 \mathrm{~m}$ depth for the south and north embankment midslope at Hawkwell between April 2006 and March 2011. The calculated vertical displacement for the north midslope stops in December 2009 as the neutron probe access tube was bent by ground movements and could no longer be read to the full depth. 
Mechanical and hydrological impacts of tree removal on a clay fill railway embankment

Smethurst J A, Briggs K M, Powrie W, Ridley A, Butcher D. J. E.

\section{Figures}

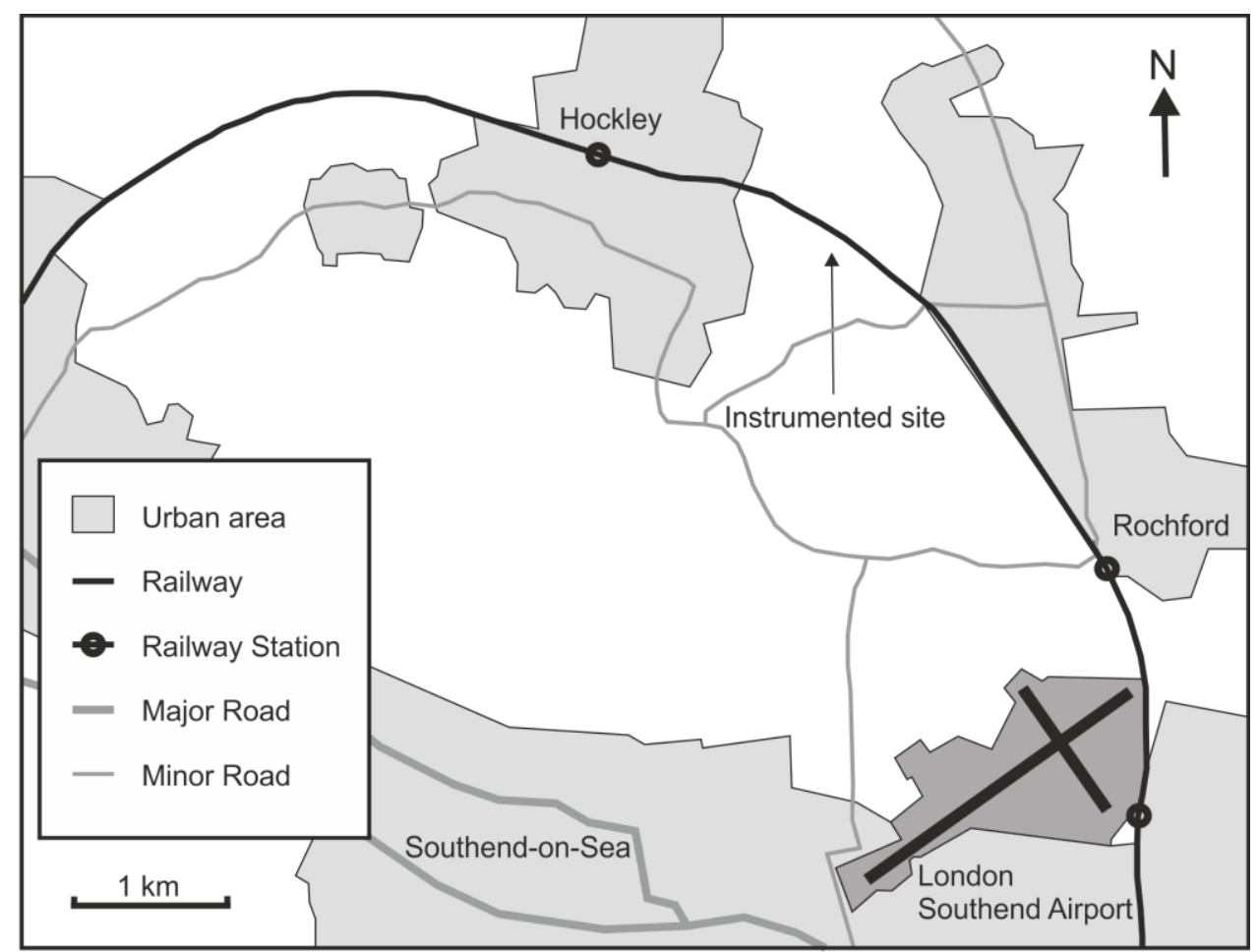

Figure 1: Location of the instrumented site 


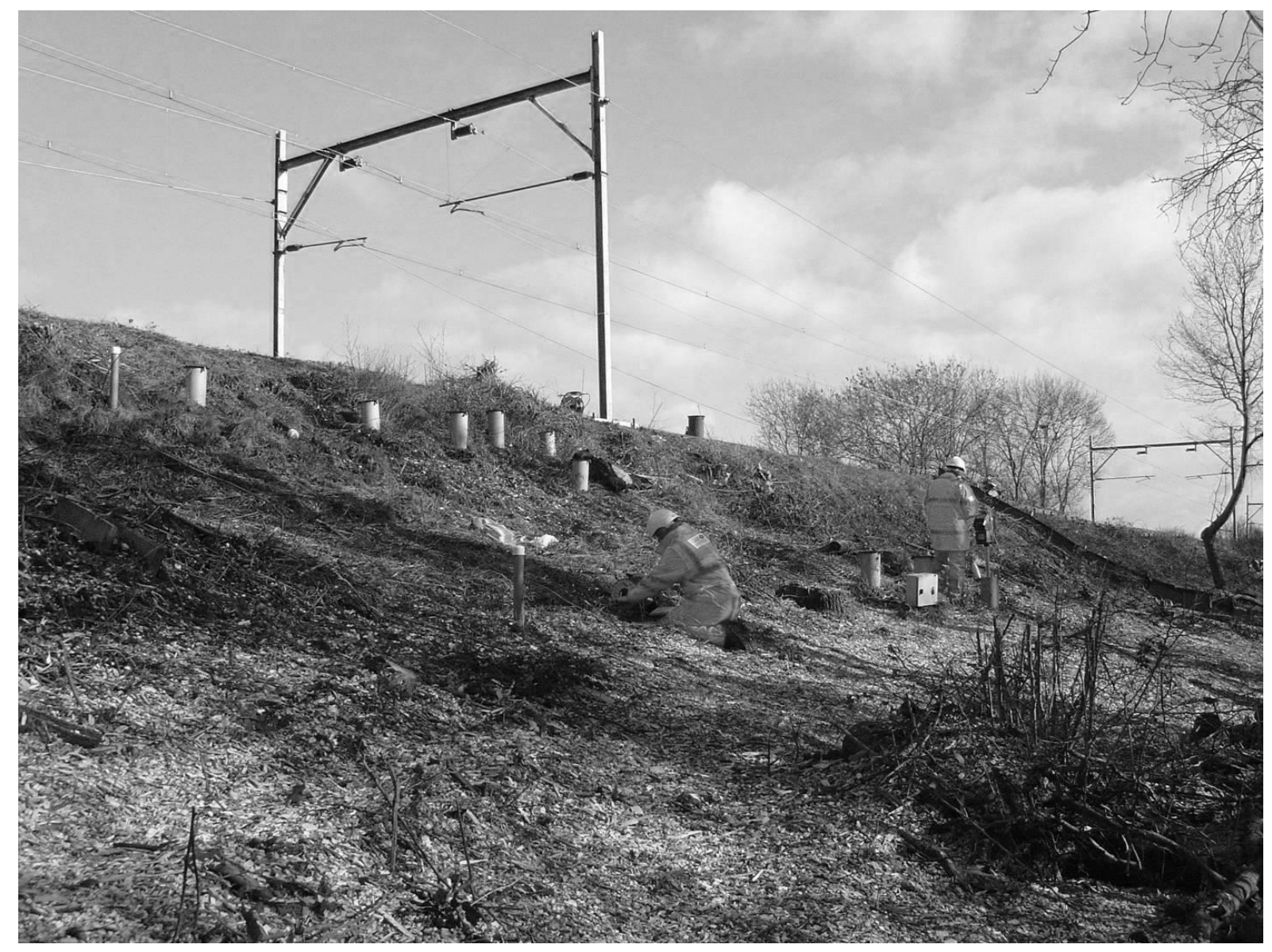

Figure 2: Photograph showing the south side of the embankment in March 2010, shortly after the second vegetation clearance. 


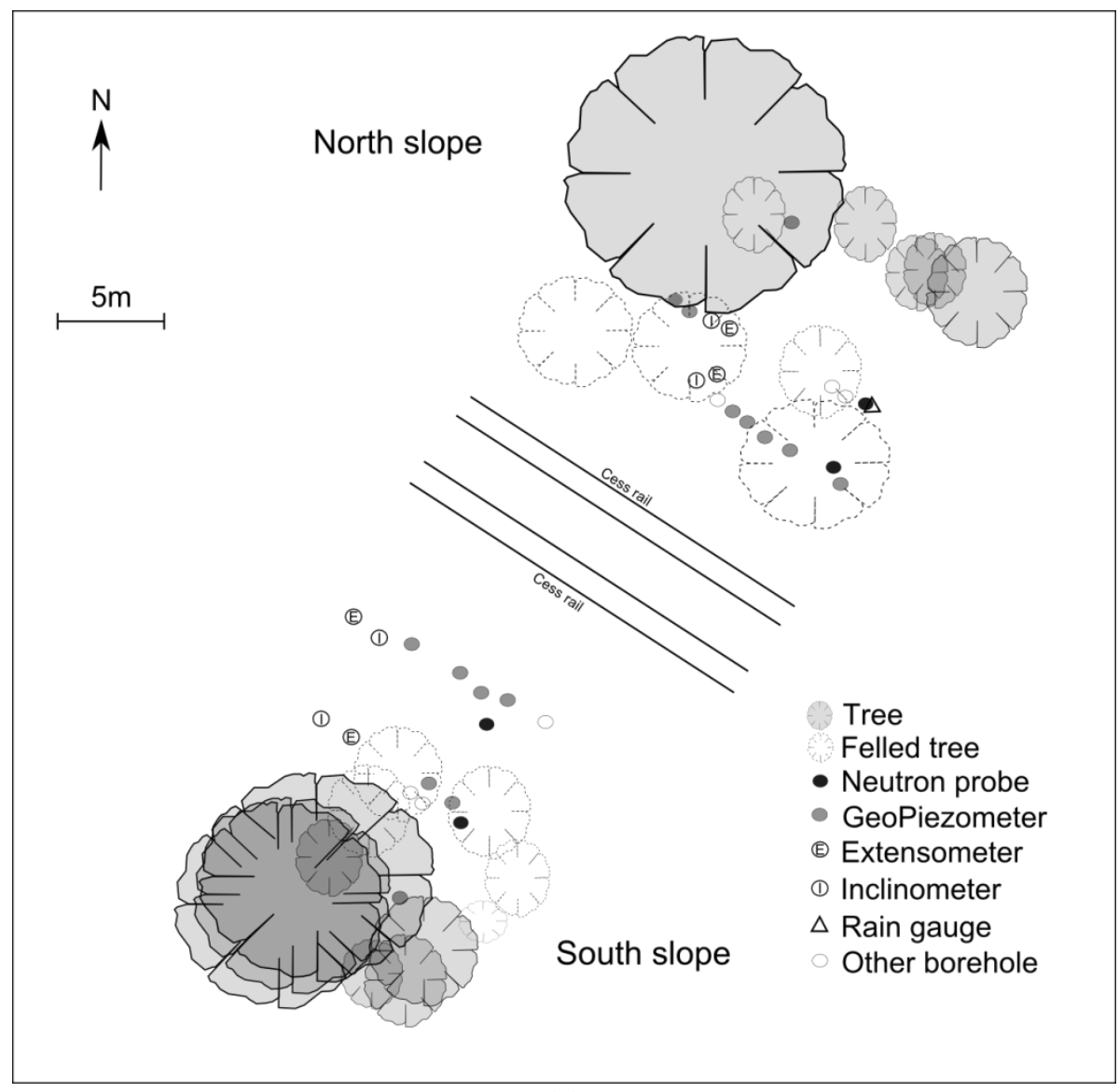

(a)

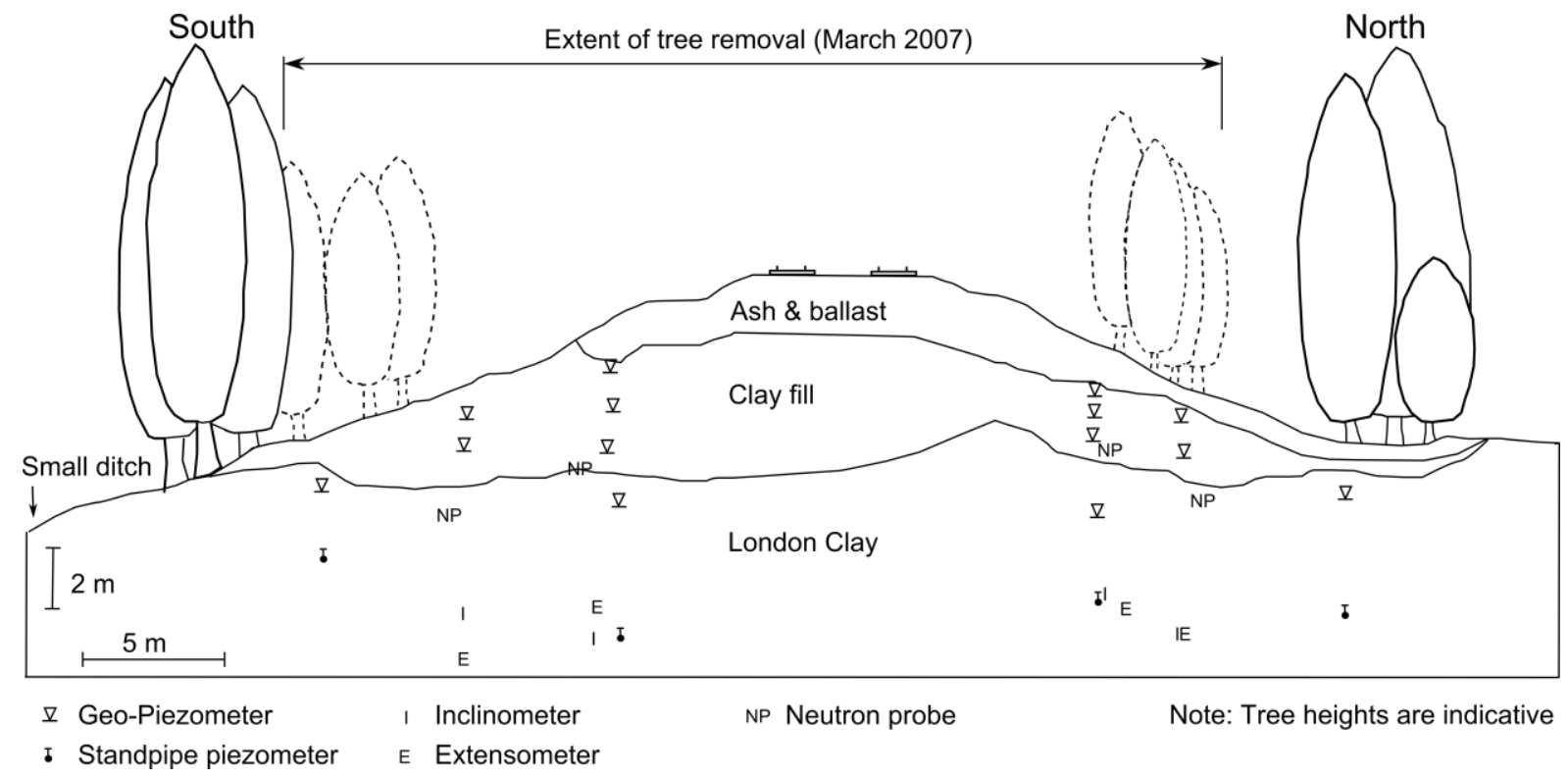

(b)

Figure 3: Location of instrumentation at Hawkwell embankment, shown (a) in plan; and (b) in cross section. In (b), the symbols mark the maximum depth of each installation, and tree form and height are not drawn to scale. Redrawn from Arup (2007). 


\section{Cone resistance and sleeve friction}

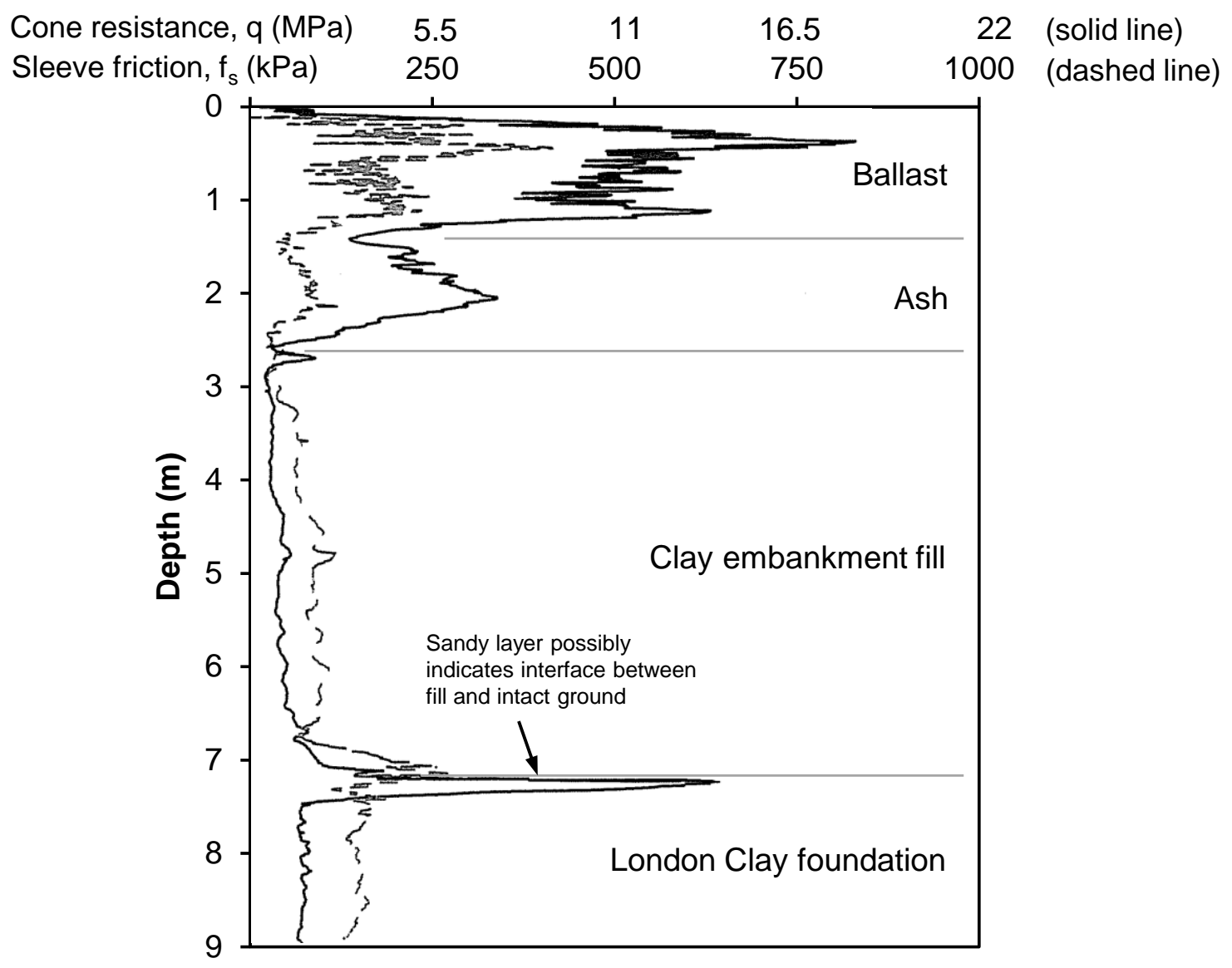

Figure 4: CPT data taken through the centre of the embankment midway between the up and down lines. 


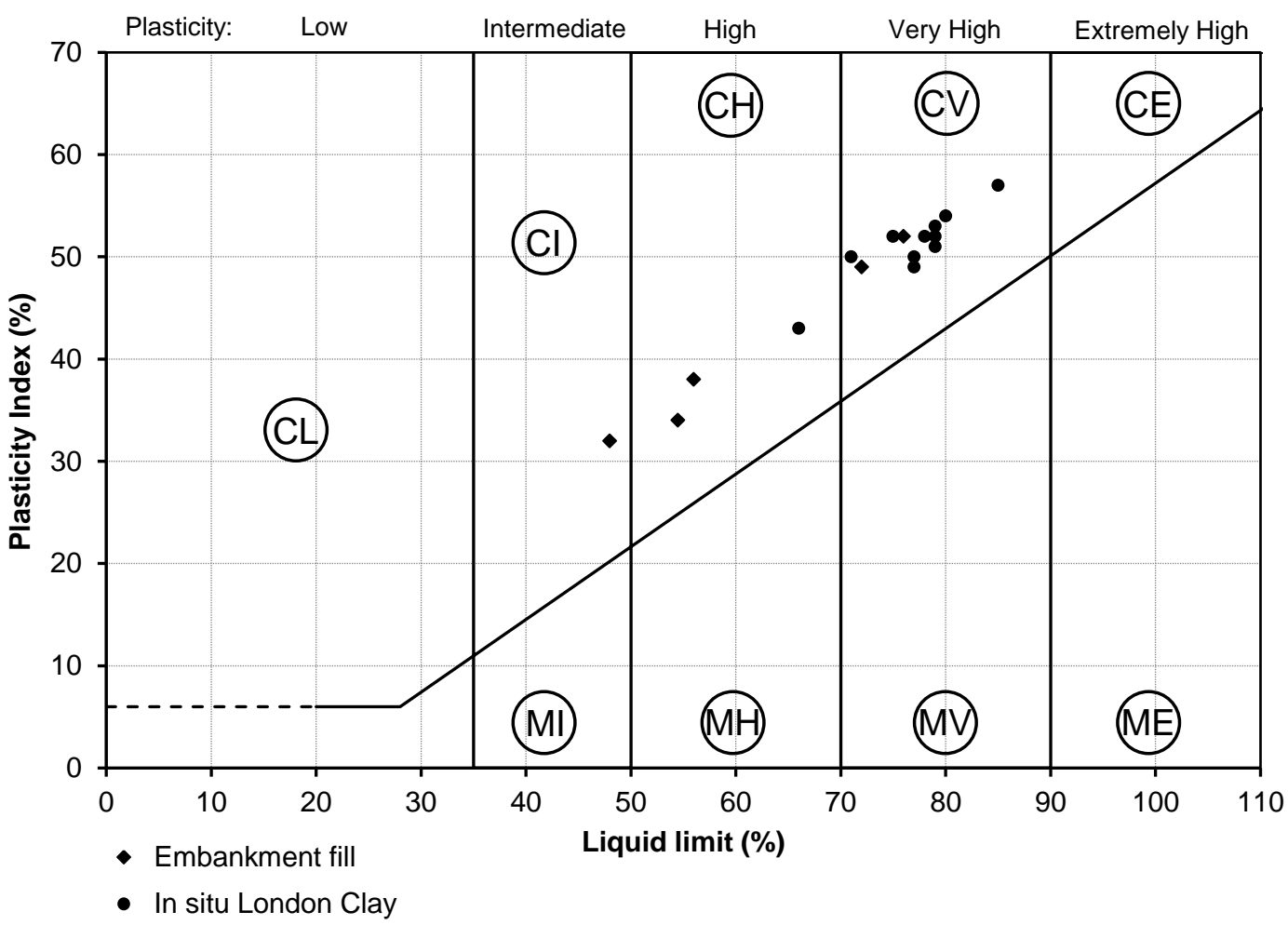

Figure 5: Plasticity of in situ London Clay and embankment fill 


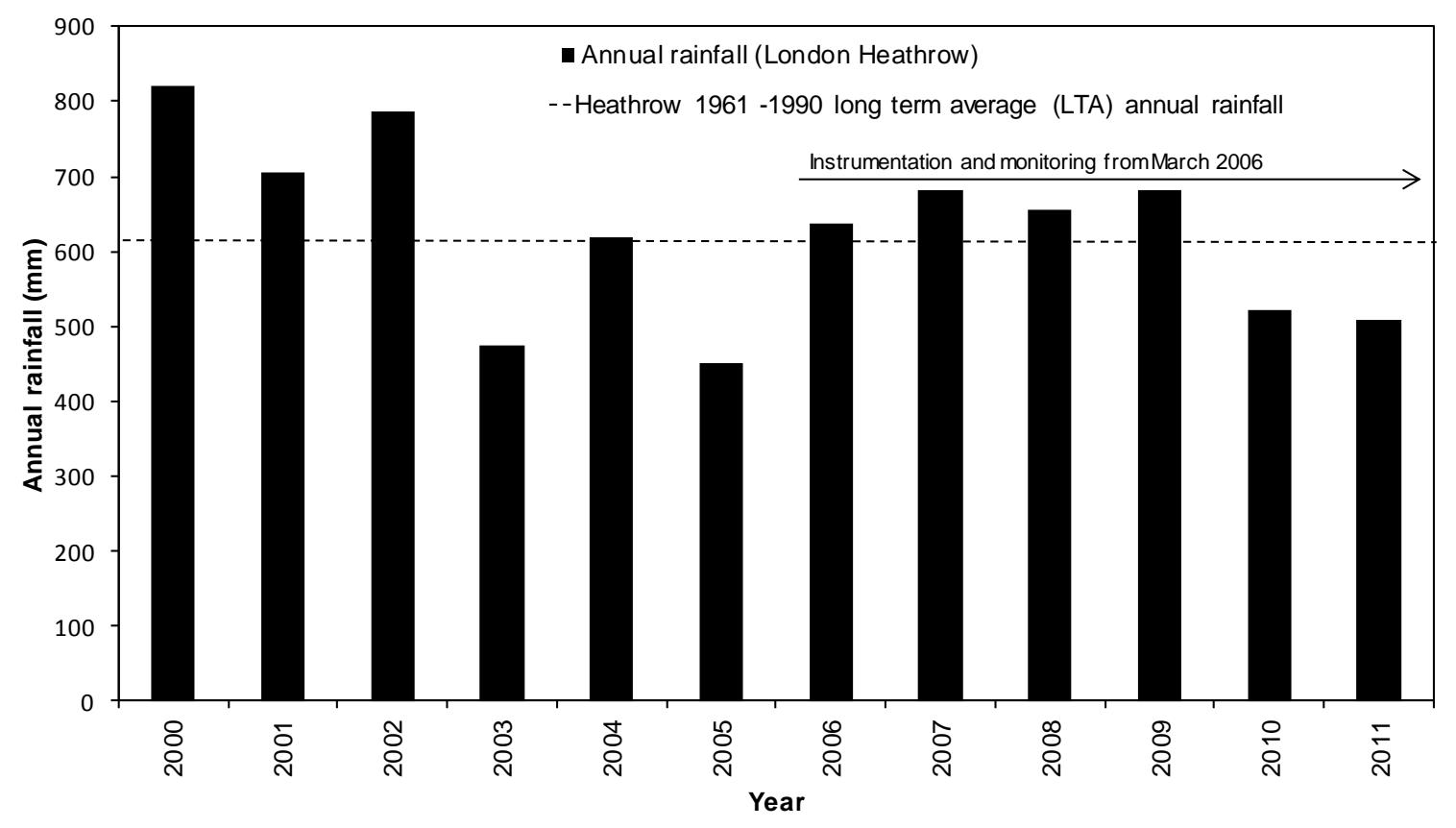

(a)

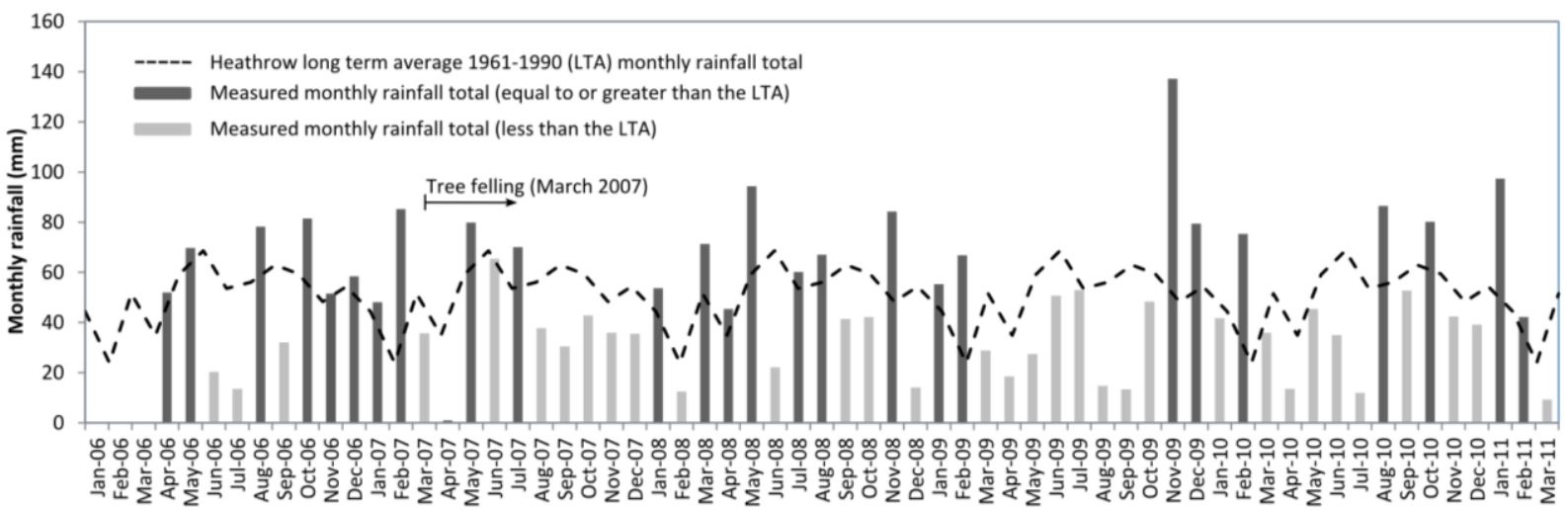

(b)

Figure 6: (a) Annual rainfall totals measured at London Heathrow (2000-2011); (b) Monthly rainfall totals measured at Hawkwell over the monitoring period. 


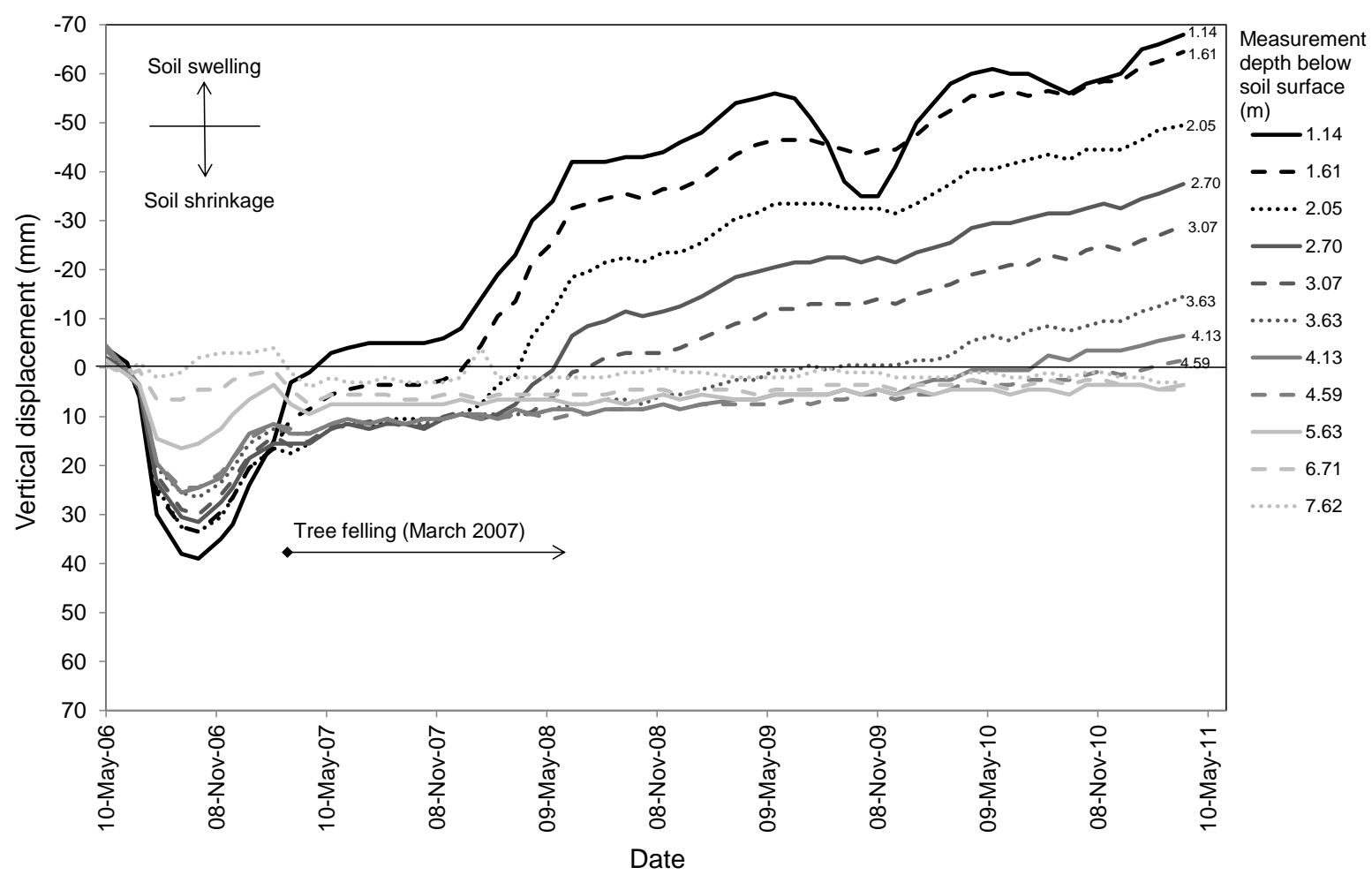

(a)

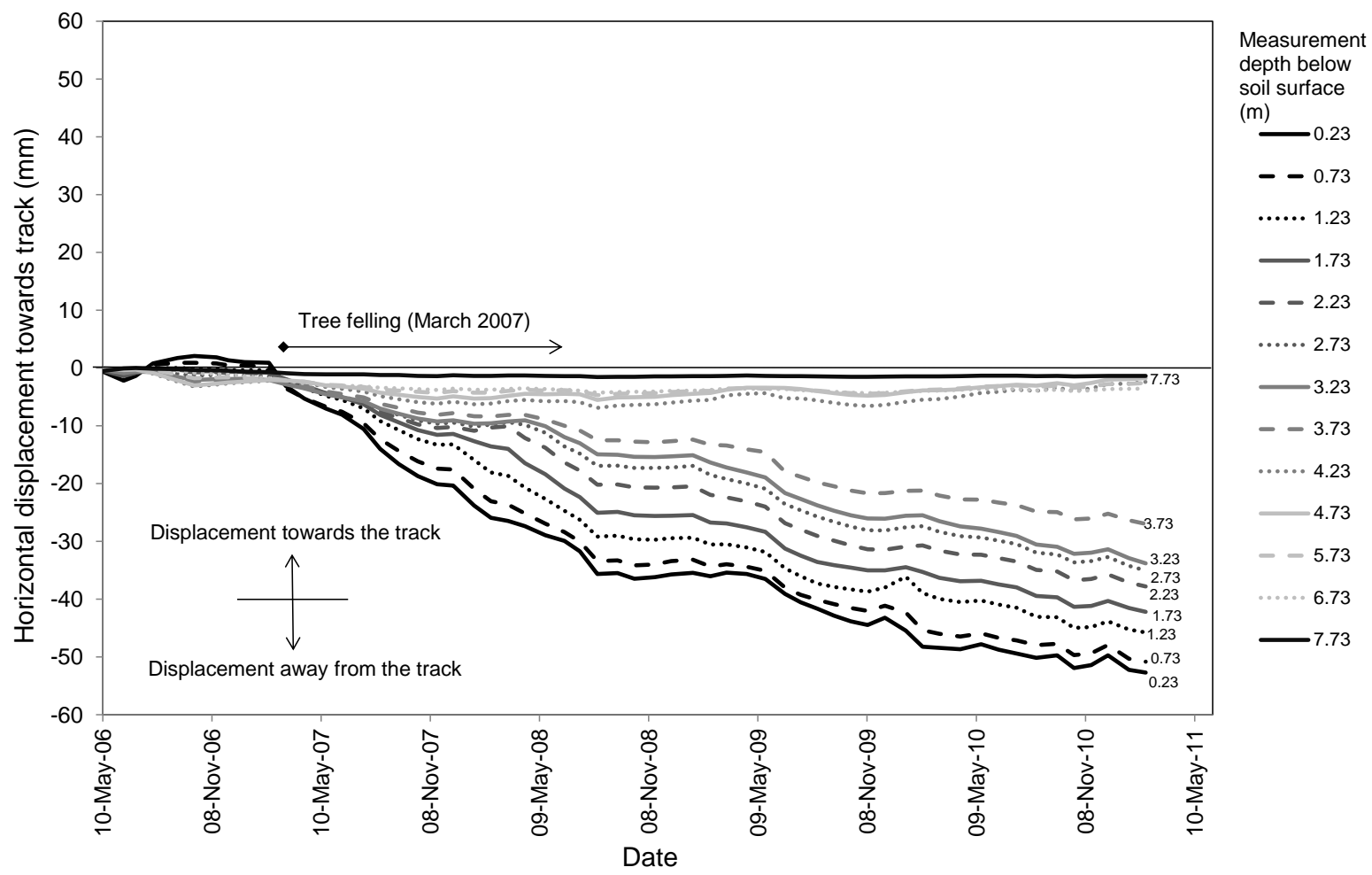

(b)

Figure 7: North crest installations: (a) vertical extensometer displacements plotted relative to initial magnet positions in April 2006; and (b) horizontal inclinometer displacements plotted relative to initial positions in April 2006. 


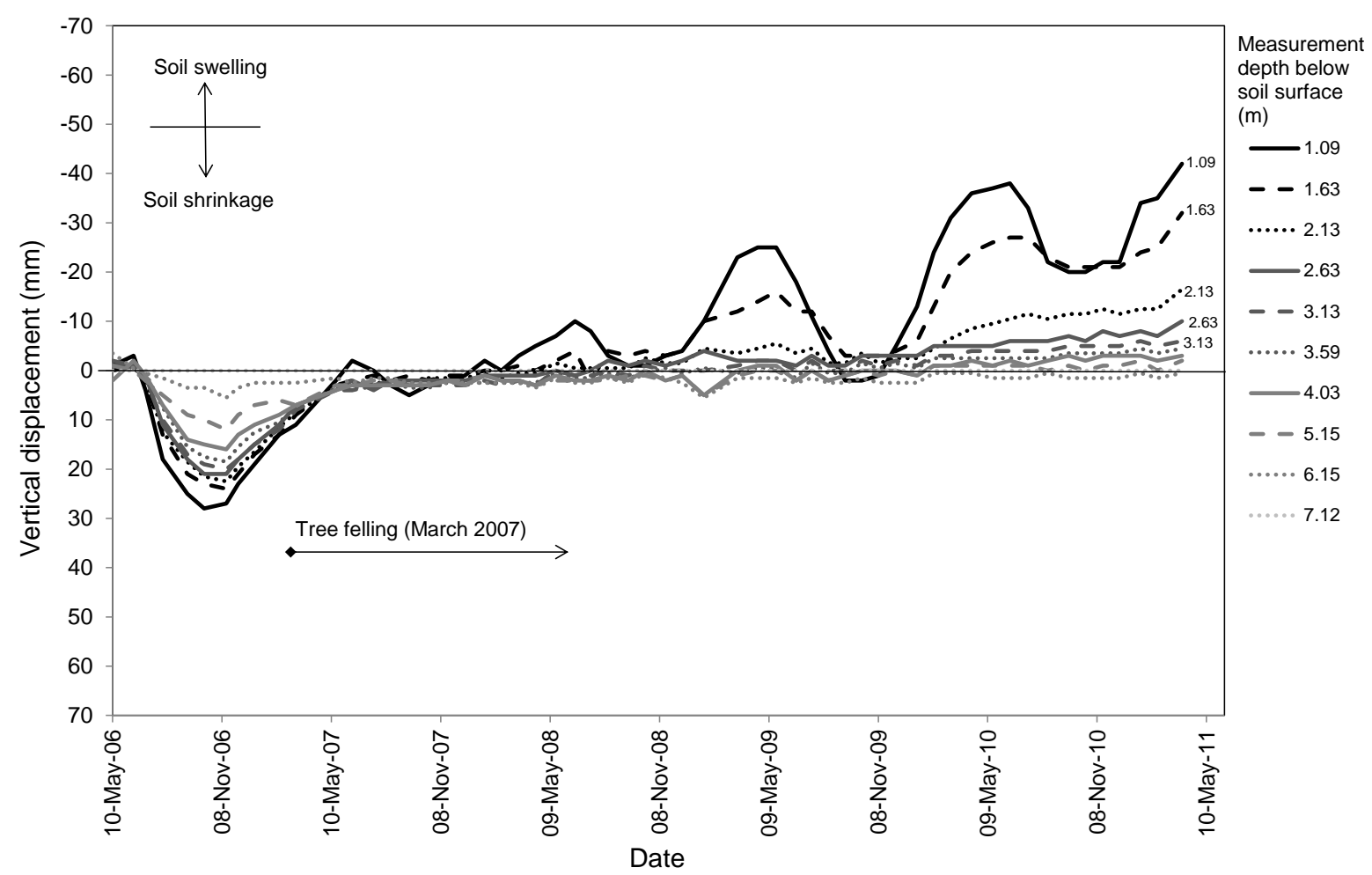

(a)

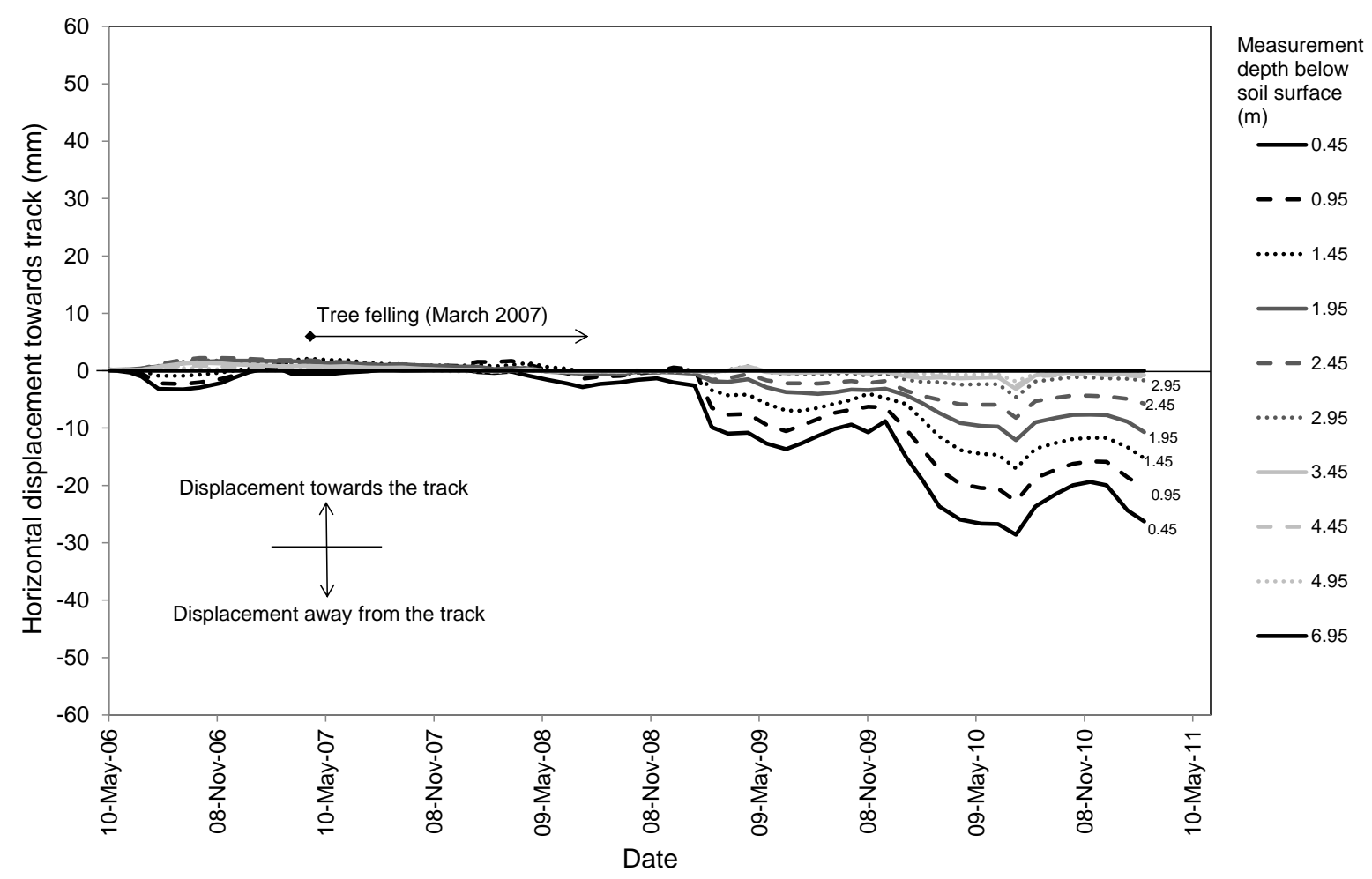

(b)

Figure 8: South midslope installations: (a) vertical extensometer displacements plotted relative to initial magnet positions in April 2006; and (b) horizontal inclinometer displacements plotted relative to initial positions in April 2006. 


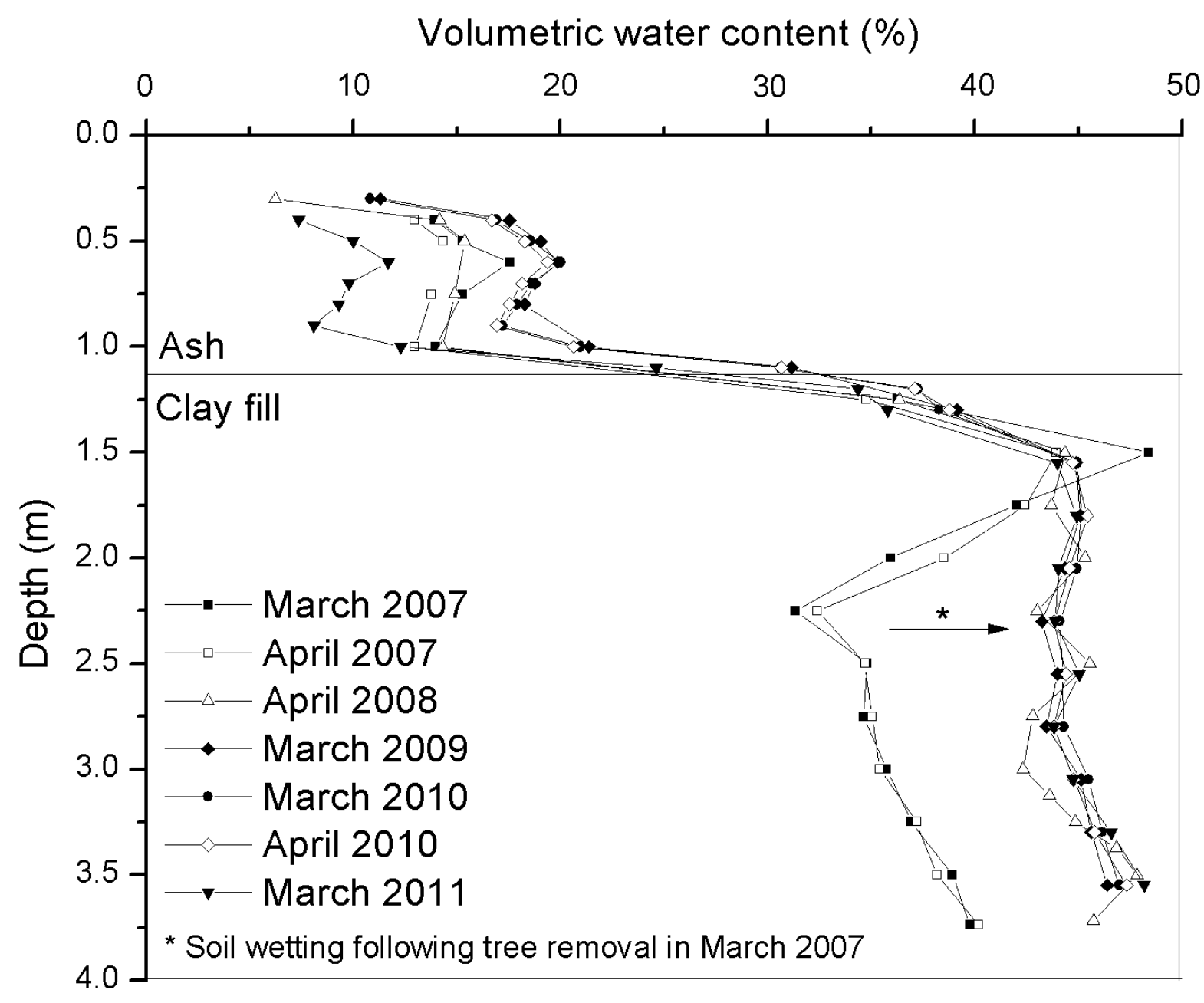

(a) 


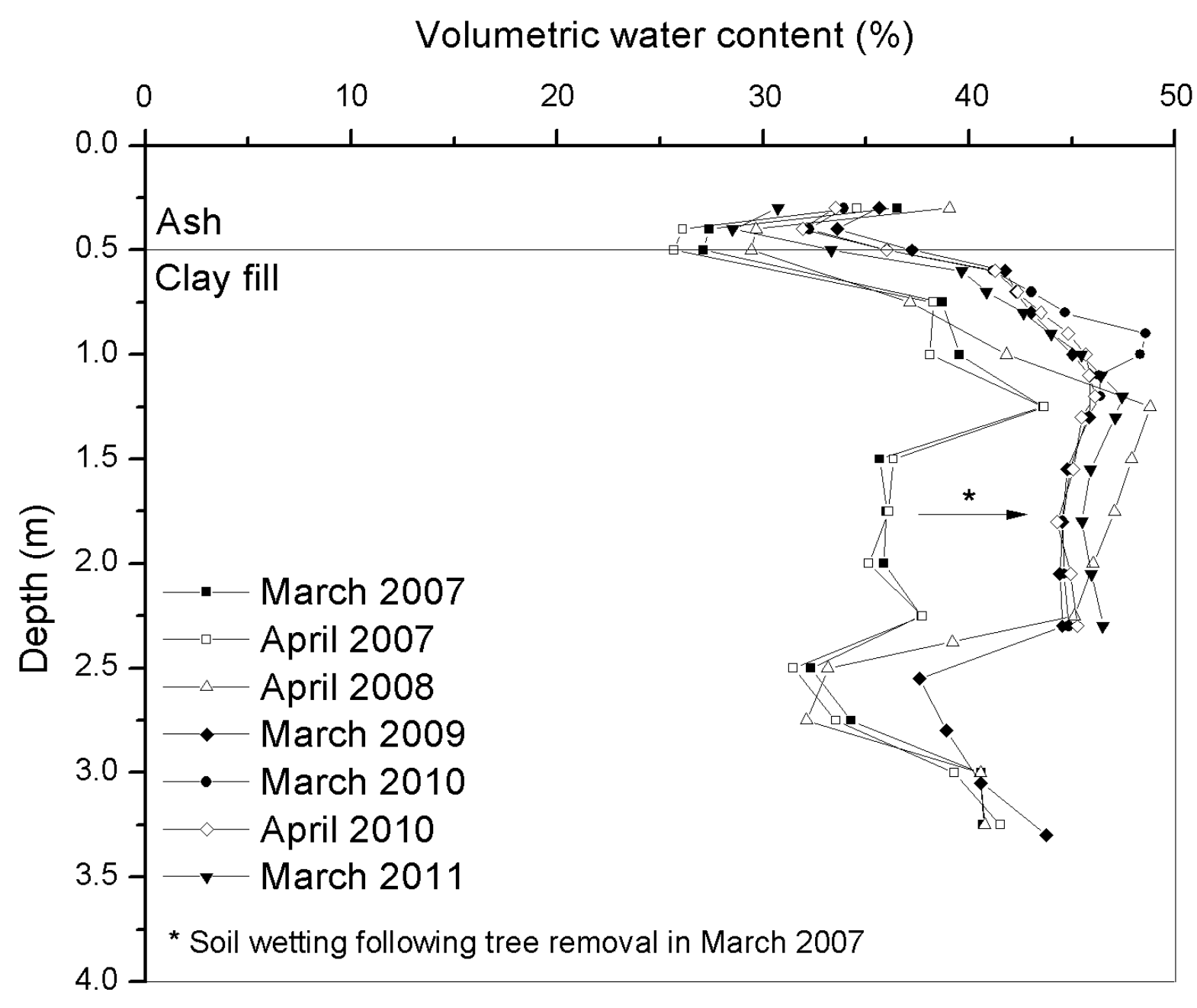

(b)

Figure 9: End of winter (March - April) volumetric water contents, north embankment slope: (a) crest; (b) midslope. 


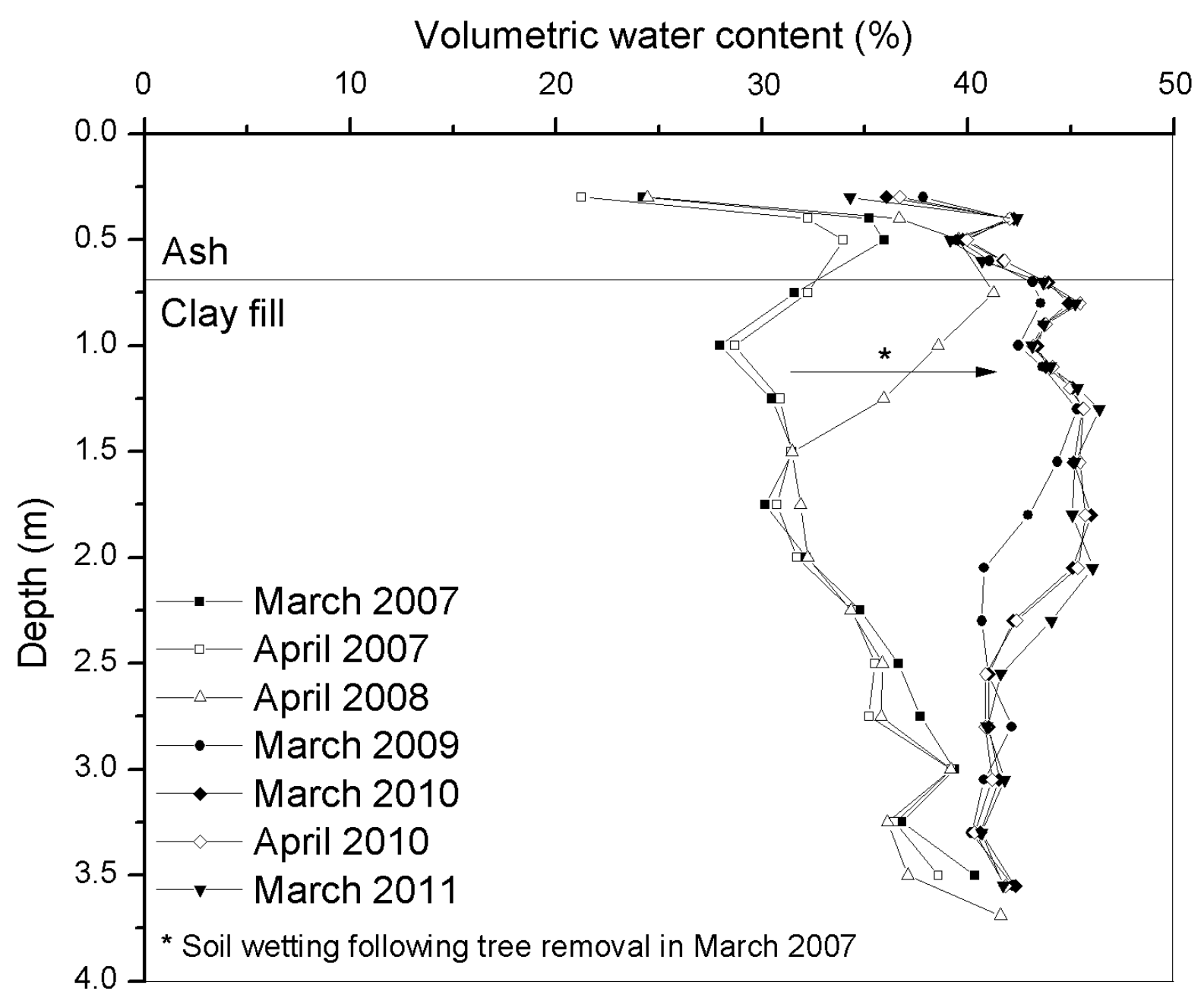

(a) 
Volumetric water content (\%)

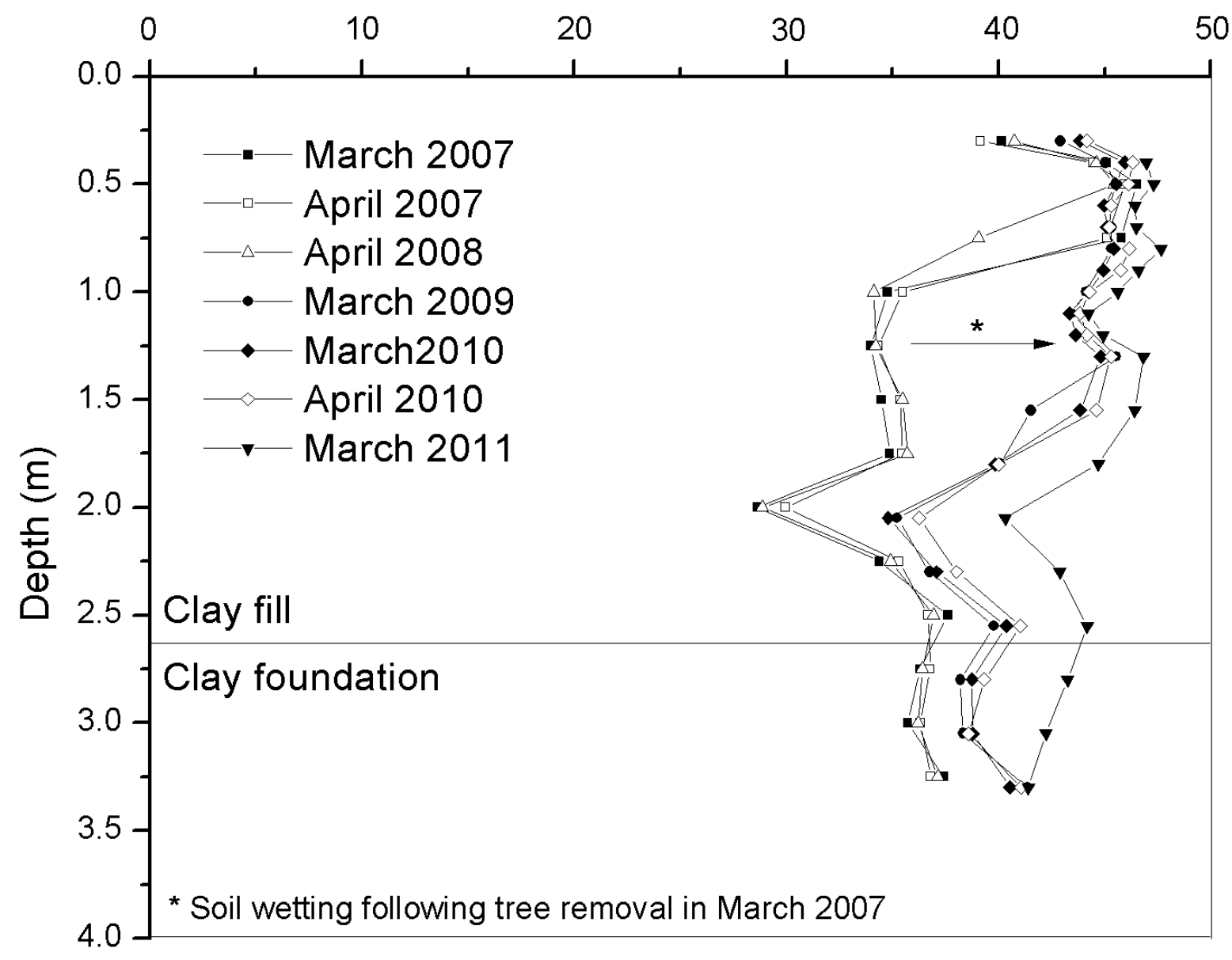

(b)

Figure 10: End of winter (March - April) volumetric water contents, south embankment slope: (a) crest; (b) midslope. 


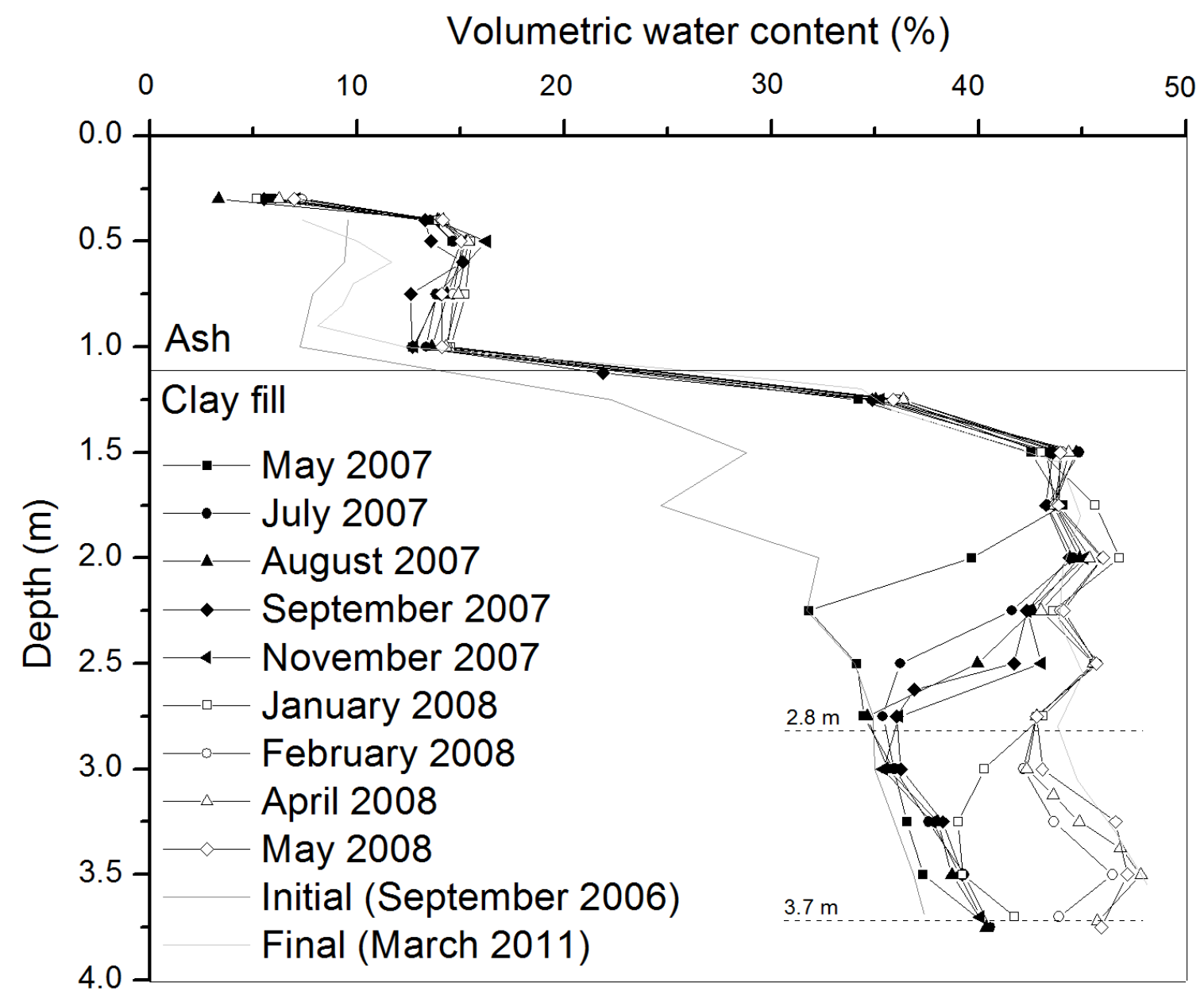

Figure 11: North crest volumetric water content variation from May 2007 to May 2008, with initial and final measurements shown for comparison 


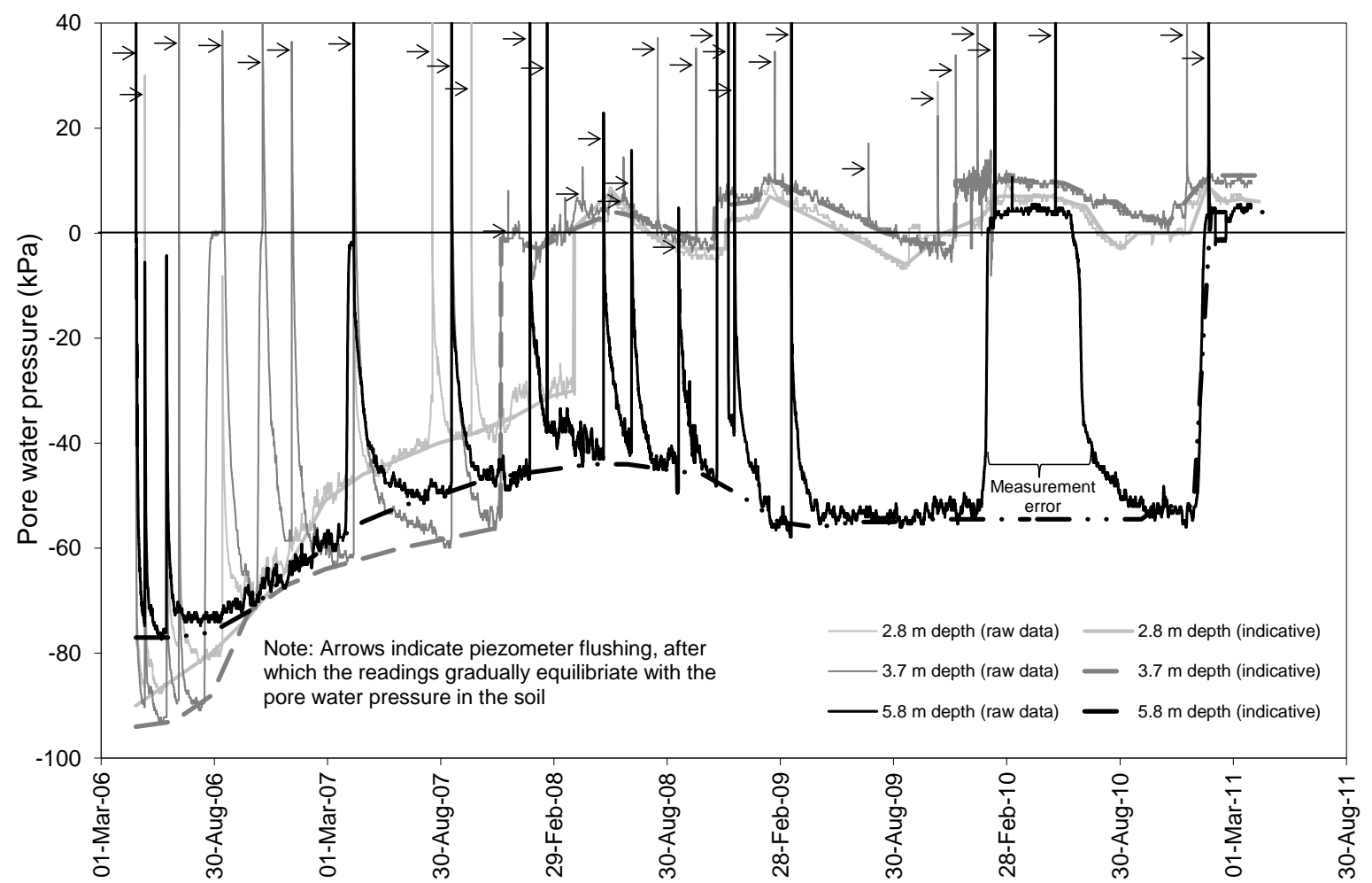

Figure 12: North crest piezometer measurements at $2.8 \mathrm{~m}, 3.7 \mathrm{~m}$ and $5.8 \mathrm{~m}$ depth, with indicative trend lines for pore water pressure shown. The spikes to positive pore pressures indicate piezometer flushing taking place, after which the readings slowly come back to equilibrium with pore water pressures in the soil. 


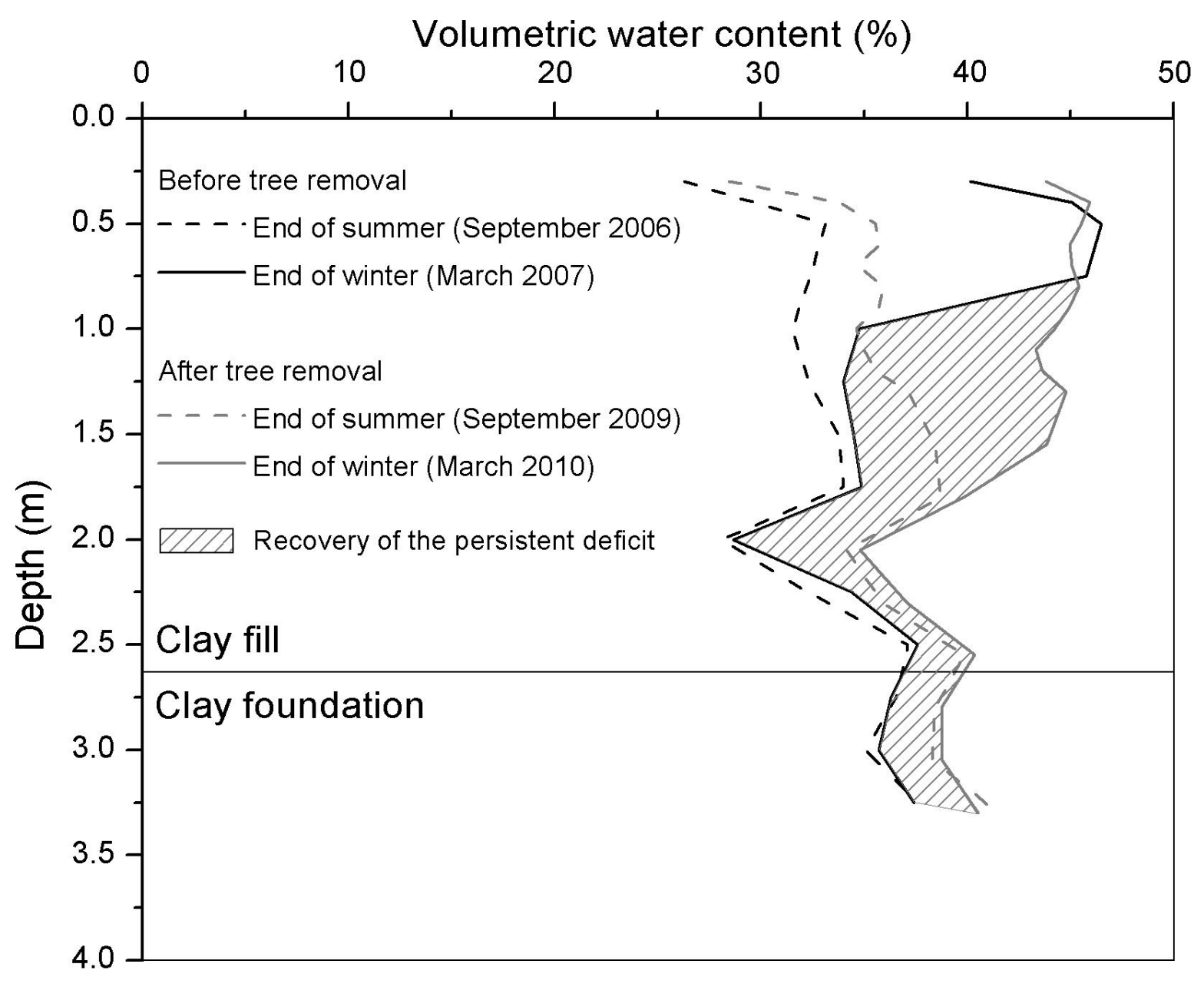

(a) 


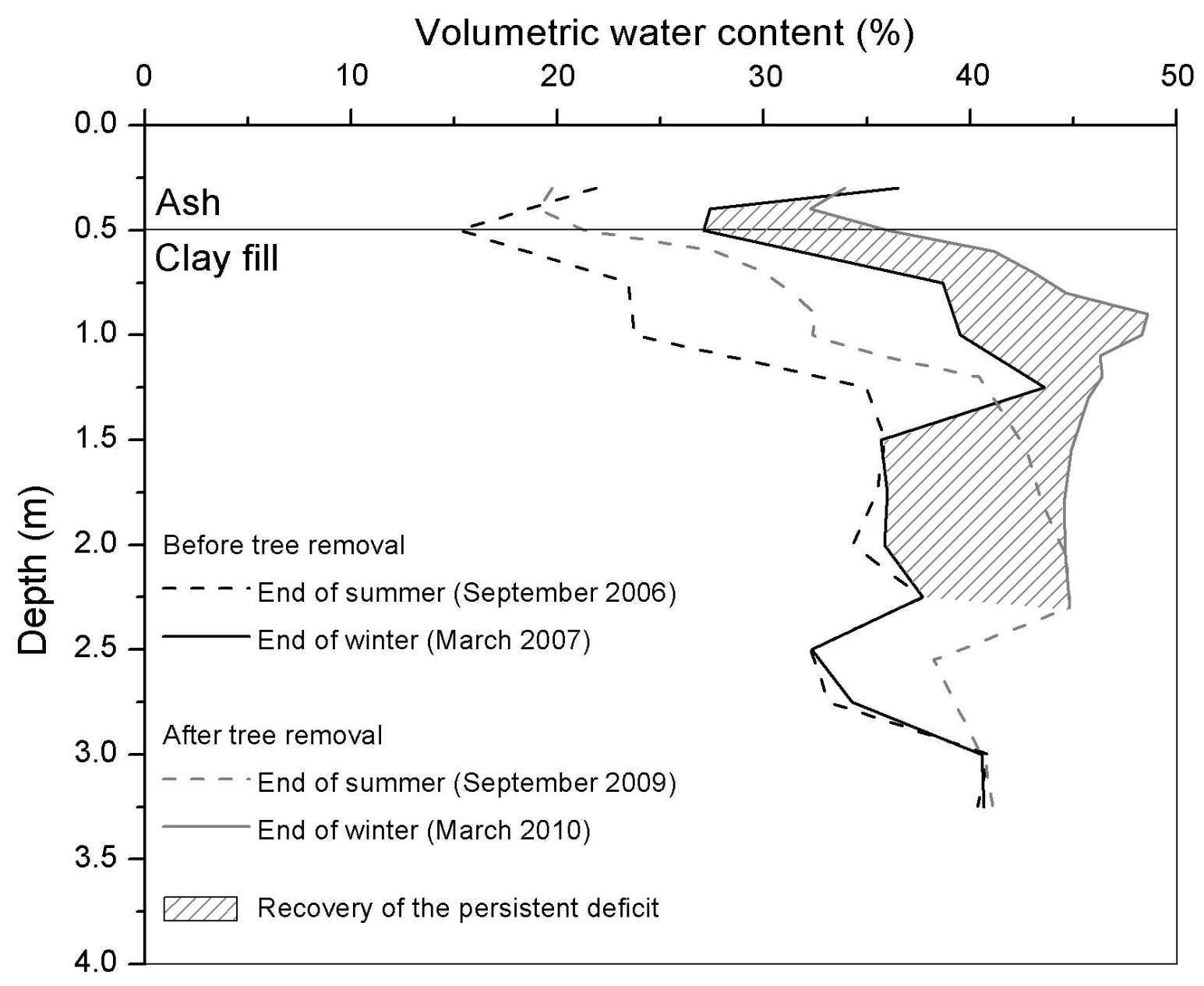

(b)

Figure 13: End of winter (March) and end of summer (September) volumetric water content before and after tree removal, at the midslope of the: (a) south slope; (b) north slope. 


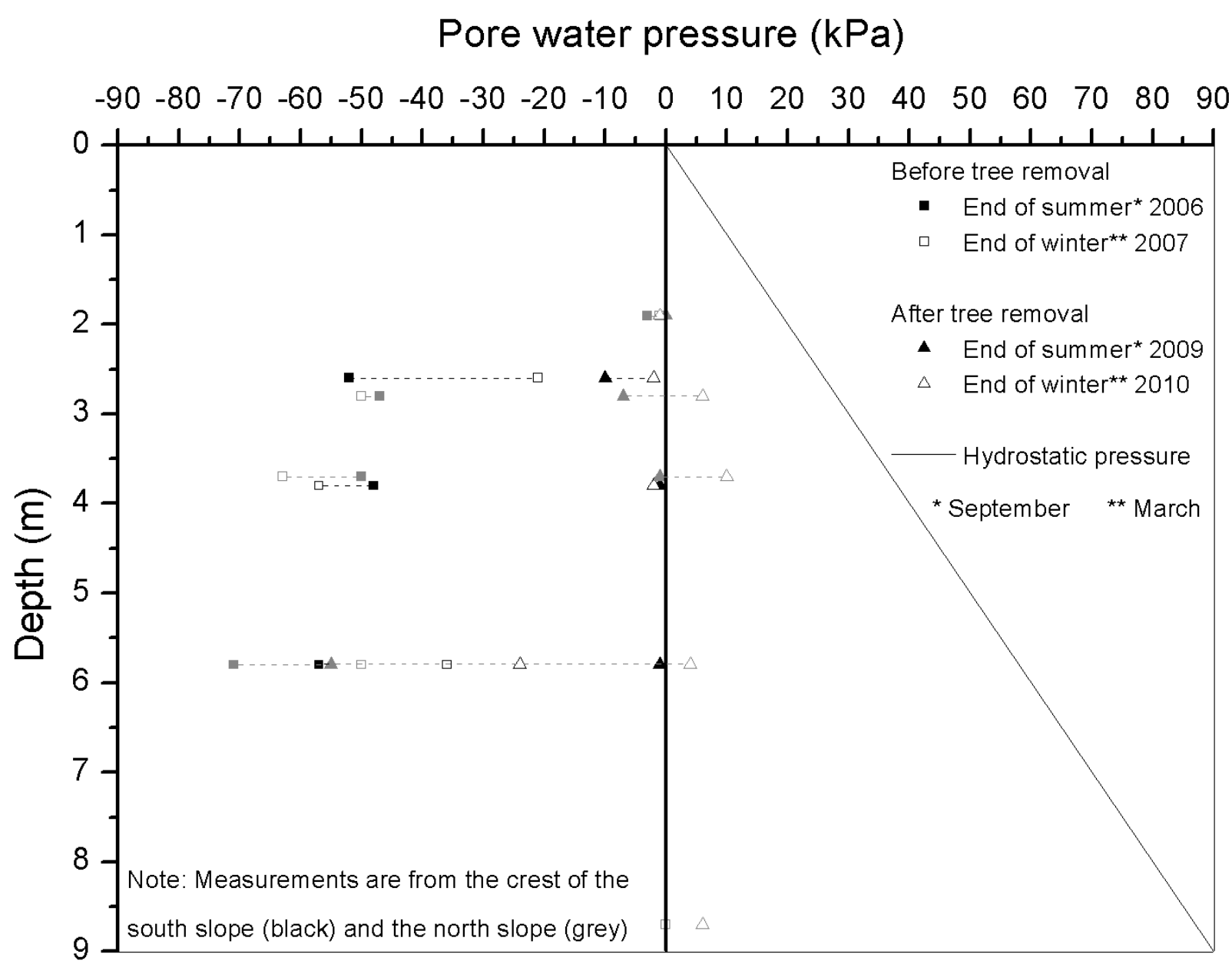

(a) 


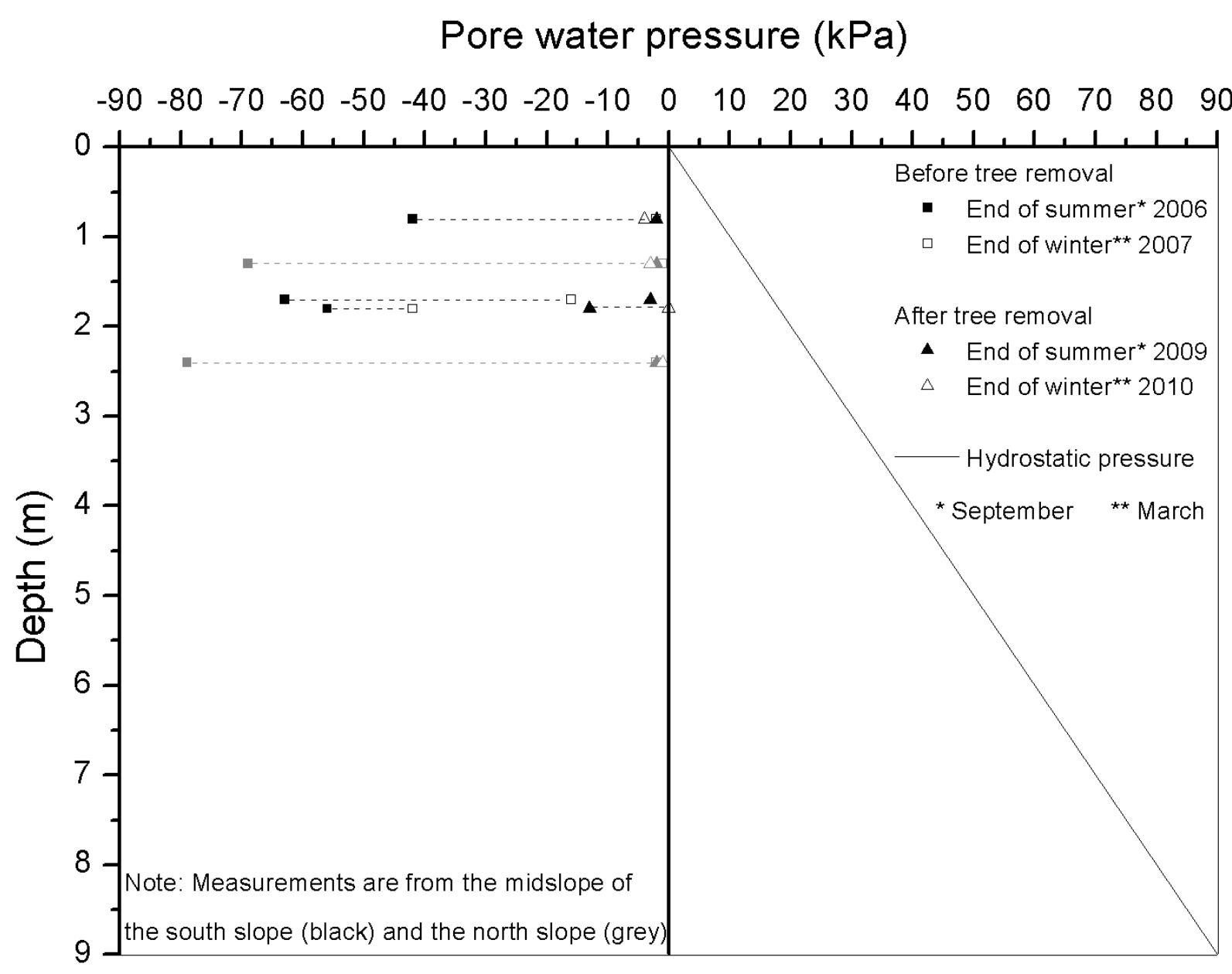

(b)

Figure 14: End of winter (March) and end of summer (September) pore water pressures before and after tree removal: (a) crest of both north and south slopes; (b) midslope of both north and south slopes. 


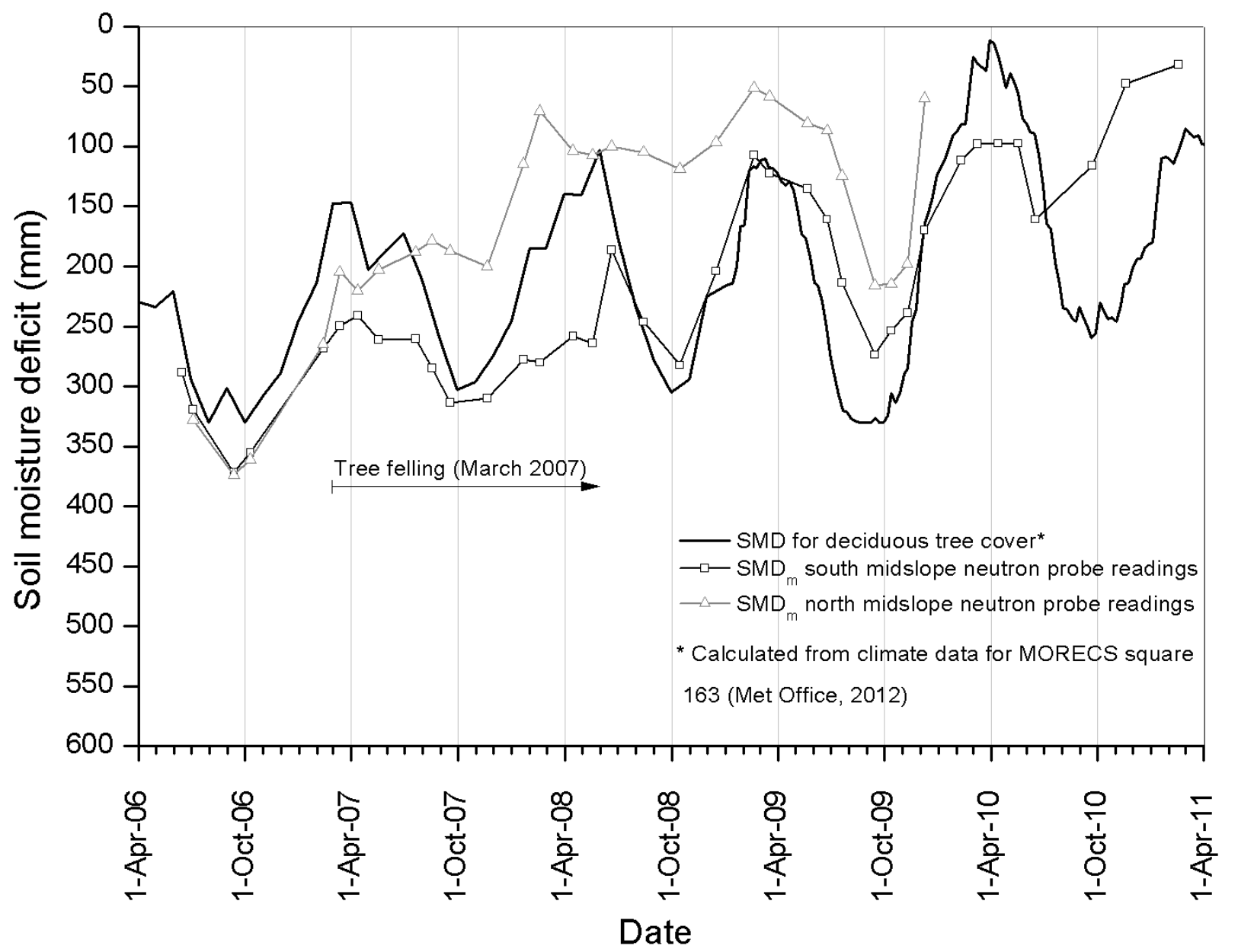

Figure 15: Comparison of soil moisture deficit $\left(\mathrm{SMD}_{\mathrm{m}}\right)$ measured at the embankment midslope with the MORECS SMD calculated from climate data (Met Office, 2012). The calculated $\mathrm{SMD}_{\mathrm{m}}$ for the north midslope stops in December 2009 as the neutron probe access tube was bent by ground movements and could no longer be read to the full depth. 


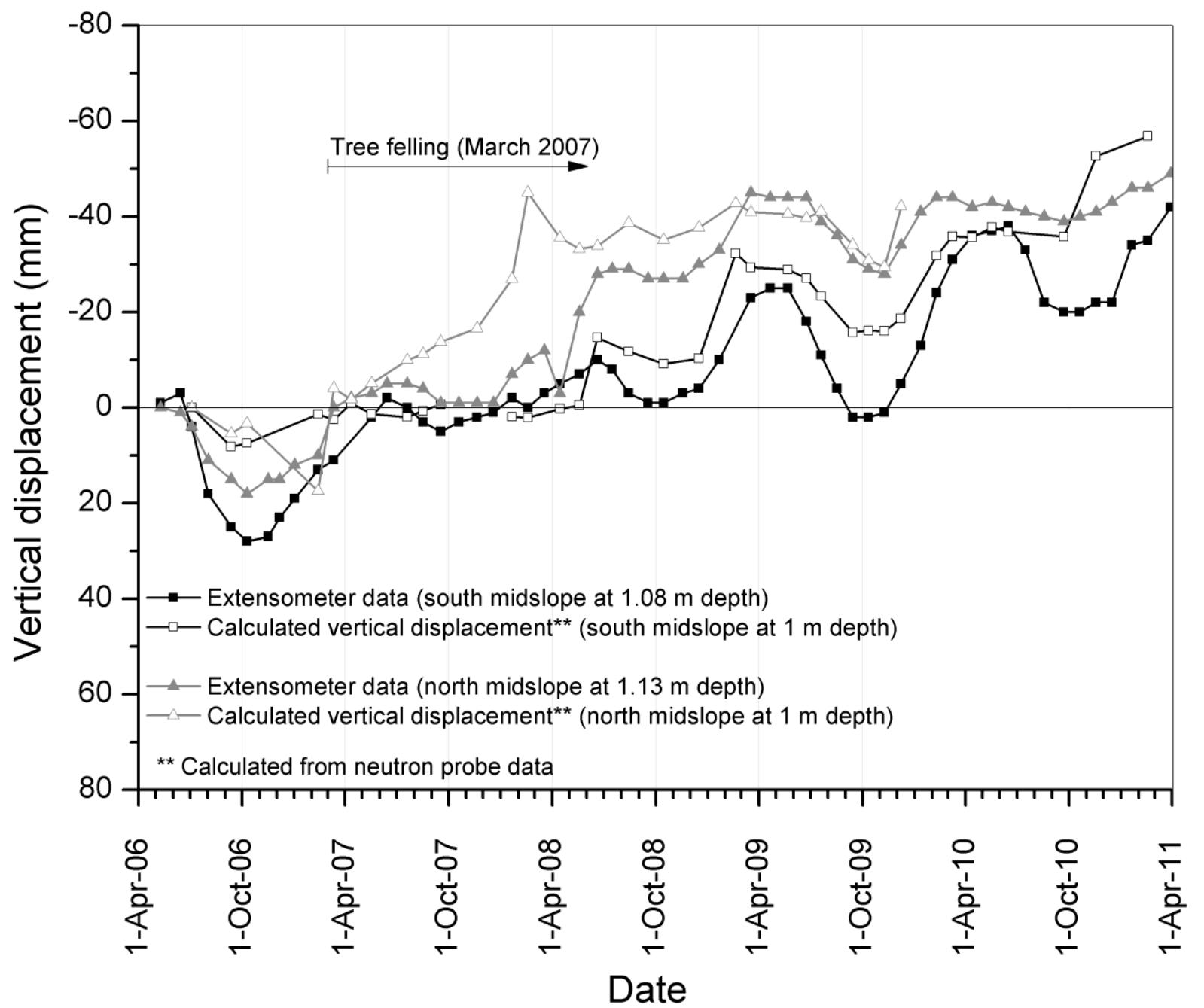

Figure 16: Comparison of measured and calculated vertical displacement at $1 \mathrm{~m}$ depth for the south and north embankment midslope at Hawkwell between April 2006 and March 2011. The calculated vertical displacement for the north midslope stops in December 2009 as the neutron probe access tube was bent by ground movements and could no longer be read to the full depth. 